\title{
A CONSTITUTIONAL ANALYSIS OF KENDRA'S LAW: NEW YORK'S SOLUTION FOR TREATMENT OF THE CHRONICALLY MENTALLY ILL
}

\author{
ILISSA L. WATNIK

\section{INTRODUCTION}

On January 3, 1999, a young woman named Kendra Webdale was tragically pushed to her death in front of an oncoming Manhattan subway train by twenty-nine-year-old Andrew Goldstein, a diagnosed schizophrenic with a history of violence who failed to take his prescribed medication.' Other similarly tragic incidents occurred that year, including the April 6 police shooting of Charles Stevens, a man with a history of mental illness who swung a sword at passengers on the Long Island Railroad. ${ }^{2}$ In another instance, on April 28, 1999, Edgar Rivera's legs were severed after Julio Perez, an untreated schizophrenic, shoved him into an oncoming subway train. ${ }^{3}$

In response to these tragedies, New York's Attorney General, Eliot Spitzer, proposed Assisted Outpatient Treatment ("AOT") legislation, which is the official name for Kendra's Law. ${ }^{4}$ On August 27, 1999, New York Governor George Pataki formally signed this legislation, named in honor of Kendra Webdale, into law. ${ }^{5}$ This statute allows particular individuals to petition the court to obtain an order for a mentally ill person to receive AOT if that person meets very specific

† B.A. 1997, Brown University; J.D. Candidate 2001, University of Pennsylvania. This Comment is dedicated to my parents, Martin and Rickey, and to my brother, Scott, for their constant support throughout my academic endeavors. In addition, I would like to thank the University of Pennsylvania Law Review editors for their much-welcomed thoughts and contributions.

'Yael Schacher, Kendra's Law Criteria, N.Y. L.J., Sept. 30, 1999, at 6.

2 Press Release, Statement by Attorney General Eliot Spitzer Regarding the Leaders' Agreement on Kendra's Law (Aug. 3, 1999), at http://www.psychlaws.org/ StateActivity/NewYork/Spitzerstatement.htm.

Id.

'Sec Eliot Spitzer, Is Kendra's Law the Answer? YES, N.Y. L.J., May 19, 1999, at 2 (announcing the proposal and emphasizing its merits).

Joel Stashenko, Law Allows Courts To Order Treatment of Mentally $M l$, BuFf. NEwS, Aug. 28, 1999, at 9A. 
and defined criteria. ${ }^{6}$

This Comment analyzes New York's approach to assisted outpatient commitment. Part I first provides a brief history of outpatient commitment in the United States and explains the legal foundation that allows a state legally to provide such an option for mentally ill individuals. Second, other states' statutory approaches to AOT are examined. Part II provides a detailed discussion of the way Kendra's Law will operate in New York, and a federal- and state-level constitutional evaluation and analysis follows. Part III provides policy justifications for, and potential barriers to, implementing Kendra's Law. Finally, Part IV discusses recent developments and cases arising under the statute.

This Comment argues that through Kendra's Law, New York has provided a less restrictive alternative than inpatient commitment for treating the mentally ill. Balancing the patient's liberty and autonomy

${ }^{6}$ N.Y. MENTAL HYY. LAW $\$ 9.60$ (c) (McKinney Supp. 2001). The statute sets out the necessary criteria for an AOT court order:

A patient may be ordered to obtain assisted outpatient treatment if the court finds that:

(1) the patient is eighteen years of age or older; and

(2) the patient is suffering from a mental illness; and

(3) the patient is unlikely to survive safely in the community without supervision, based on a clinical determination; and

(4) the patient has a history of lack of compliance with treatment for mental illness that has:

(i) at least twice within the last thirty-six months been a significant factor in necessitating hospitalization in a hospital, or receipt of services in a forensic or other mental health unit of a correctional facility or a local correctional facility, not including any period during which the person was hospitalized or incarcerated immediately preceding the filing of the petition or; [sic]

(ii) resulted in one or more acts of serious violent behavior toward self or others or threats of, or attempts at, serious physical harm to self or others within the last forty-eight months, not including any period in which the person was hospitalized or incarcerated immediately preceding the filing of the petition; and

(5) the patient is, as a result of his or her mental illness, unlikely to voluntarily participate in the recommended treatment pursuant to the treatment plan; and

(6) in view of the patient's treatment history and current behavior, the patient is in need of assisted outpatient treatment in order to prevent a relapse or deterioration which would be likely to result in serious harm to the patient or others as defined in section 9.01 of this article; and

(7) it is likely that the patient will benefit from assisted outpatient treatment; and

(8) if the patient has executed a health care proxy as defined in article 29-C of the public health law, that any directions included in such a proxy shall be taken into account by the court in determining the written treatment plan. 
interests against the State's police power and parens patriae interests leads to the conclusion that the State's interests outweigh the patient's interests. Under this analysis, Kendra's Law does not violate substantive due process. Furthermore, the procedural safeguards that are built into the statute lessen the likelihood of an erroneous deprivation of liberty. Ironically, Kendra's Law actually increases a patient's liberty in a system where the only alternatives would be either inpatient commitment or physical freedom subject to the mental imprisonment caused by the illness. Critics' central argument against the statute is that it violates a patient's right to determine her own course of treatment; however, Kendra's Law permits the patient to participate in the development of a treatment plan. Furthermore, it does not authorize involuntary medication, thereby upholding the state constitutional and common law right to refuse treatment. Finally, the most serious potential barrier to the successful implementation of Kendra's Law would be lack of adequate funding. It is uncertain at this time whether the budgetary provisions made for Kendra's Law will prove sufficient to carry out its objectives. The option for AOT is meaningless unless the resources are available to implement it.

Kendra's Law is crucial to preventing tragedies, such as the Kendra Webdale incident, from occurring again. An estimated one thousand homicides are committed each year by untreated mentally ill individuals. ${ }^{7}$ In addition, the suicide rate among the mentally ill is ten to fifteen times higher than among the general population. ${ }^{8}$ Fifty percent of mentally ill individuals suffer from a symptom called "lack of insight," which causes the person not to recognize her illness and, therefore, to refuse to take the medication necessary to treat it. ${ }^{9}$

${ }^{7}$ Set E. Fuller Torrey \& Mary T. Zdanowicz, Hope for Cities Dealing with the Mental Illuess Crisis, NATION's CITIES WKLY., Apr. 19, 1999, at 2 (discussing societal implications arising from mental illness).

"Id.

"The majority of patients who lack insight, awareness or consciousness of their disease, are indifferent to it and reject the need for treatment... Thus, the patient will deny having any disease, refuse to acknowledge any symptom, and feel it is appropriate to refuse treatment. Indeed, this usually manifests itself as belligerency towards both the treatment and the individual supplying the treatment. This belligerency manifests itself in the dilemma that persons who do not know of their illness cannot adequately make the decision to refuse treatment, thereby affecting any possibility of restoring their decision making ability.... Impaired insight is the single most important reason why the mentally ill do not take medications regularly and is thus the most important cause of relapse.

Paul F. Stavis, The Nexum: A Modest Propasal for Self-Guardianship by Contract: A System of Advanit Directives and Sumogate Committes-at-Large for the Intermittently Mentally Ill, $16 \mathrm{~J}$. 
Proper implementation of Kendra's Law will target such individuals and treat them before their illness results in tragedy to themselves or others.

The need for a law such as Kendra's Law is evidenced by the ironic fact that Andrew Goldstein had twice attempted voluntarily to participate in the Bellevue Pilot Program (the precursor to Kendra's Law), but was turned away. ${ }^{10}$ Although a law such as Kendra's Law would not have helped in the specific case of Andrew Goldstein, who had sought help on his own but was rejected due to lack of space at mental health facilities, ${ }^{11}$ it would be a good place to start improving the lives of the mentally ill, as well as the public safety.

\section{SURVEY OF OUTPATIENT COMMITMENT}

\section{A. Background of Outpatient Commitment}

AOT has developed as the direct result of deinstitutionalization in the United States. ${ }^{12}$ The deinstitutionalization movement began in 1955, when the first effective antipsychotic medication-chlorpromazine, or Thorazine-was introduced. ${ }^{13}$ The states were financially responsible for patients while they were in state hospitals, but were able to shift the burden to the federal government by discharging them. ${ }^{\text {1t }}$ Medicaid was enacted in 1965, and the federal government specifically excluded Medicaid payments for patients in state psychiatric hospitals and other "institutions for the treatment of mental diseases"

CONTEMP. HEALTH L. \& POL'y 1, 21-22 (1999) (citations omitted); see also infra notes 225-26 and accompanying text (explaining the theoretical justifications for such legislation in terms of the necessities of "lack of insight").

${ }_{10}^{10}$ Michael Winerip, Behind One Man's Mind, N.Y. TIMES, Dec. 26, 1999, \$ 4, at 3.

11 See Dateline NBC: Deadly Encounter; Murder of Kendra Webdale and Trial of Her Killer, Andrew Goldstein (NBC television broadcast, July 16, 2000), LEXIS, NBC News File ("Repeatedly, our investigation found that he asked to live in a group home or psychiatric hospital, someplace where he would be watched. But each time, the hospitals discharged Goldstein after a few days or weeks at most."). Hospitals were under pressure to release Goldstein, as, "[i]n the new world of managed care, insurance payments for schizophrenics only stay at maximum levels for about three weeks or until the patient is stabilized, then the compensation goes down dramatically." Id.

${ }^{12}$ See, e.g., E. Fuller Torrey \& Robert J. Kaplan, A National Survey of the Use of Outpatient Commitment, 46 PSYCHIATRIC SeRVICES 778, 778 (1995) (reviewing the extent of outpatient commitment in the United States).

${ }^{13}$ See Treatment Advocacy Center, Homelessness, Incarceration, Episodes of Violence: Way of Life for Almost Half of Americans with Untreated Severe Mental Illness, at http://www.psychlaws.org/GeneralResources/fact2.htm (last visited Apr. 16, 2001) (recounting the history of deinstitutionalization).

${ }^{14}$ Id. 
("IMDs"). ${ }^{15}$ The purposes of excluding the payments were both to foster deinstitutionalization and to shift costs back to the states, where the federal government considered the responsibility to lie. ${ }^{16}$ In response, the states transferred massive numbers of patients to nursing homes and to the community, where Medicaid reimbursement was available. ${ }^{17}$ As a result of the incentives created by Medicaid programs, more than ninety percent of state psychiatric hospital beds have been eliminated since 1960 and an estimated forty-four psychiatric hospitals closed nationwide in the 1990s. ${ }^{18}$

Another explanation for the deinstitutionalization movement is "the inadequacy of treatment in most public mental hospitals." Many of these facilities were overcrowded, physically decayed, understaffed, and had limited or nonexistent psychotherapy. ${ }^{20}$ The community treatment approach was also

motivated by the clinical recognition that institutional existence tends to foster passive and dependent behavior.... [This] approach recognizes the drawbacks of segregating the mentally ill from the rest of society, and instead seeks to assist patients in developing or maintaining their "basic social capacities" and to foster independence and initiative.

The 1960s deinstitutionalization movement was also motivated by a concern for the civil rights of patients, signified by the creation of more stringent standards for civil commitment and by procedural and substantive due process safeguards, such as the right to treatment in the least restrictive environment. ${ }^{22}$ The doctrine of the least restrictive alternative (or least restrictive environment or setting) refers to treatment in a setting that preserves the individual's freedom and

1. Id. "IMDs were defined by the federal government as institutions or residences in which more than 16 individuals reside, at least half of who [sic] have a primary psychiatric diagnosis." Id. (internal quotation omitted).

${ }_{17}^{17}$ Id.

${ }^{17}$ Id.

${ }^{\text {is }}$ See id. (stating that in 1955 there were 559,000 patients with serious brain disorders in state psychiatric hospitals, compared with less than 70,000 today).

"Valerie J. Wilkinson, Comment, 1986 Amendments to Georgia's Mental Health Statutes: The Latest Attempt To Provide a Solution to the Problem of the Chronically Mentally Ill, 36 EMORY' L.J. 1313, 1320 (1987).

"Id.

Id. at 1320-21 (footnotes omitted).

¿2 See Antony B. Klapper, Comment, Finding a Right in State Constitutions for Community Treatment of the Mentally $I l, 142$ U. PA. L. REV. 739, 751 (1993) (noting that in the 1960 s states began to "enact new laws to protect the liberty interests of the mentally ill"). 
autonomy to the greatest extent possible. ${ }^{23}$

The goals of the deinstitutionalization movement were to provide a continuum of community-based services for the mentally ill, with minimal use of institutionalized care, as well as to furnish treatment in the least restrictive settings and utilize preventive mental health care. ${ }^{24}$ These goals, however, have not been fully realized. Many chronically ill individuals do not receive treatment and, as a result, "have become homeless or .... 'transinstitutionalized' into nursing homes, prisons, and jails." According to two prominent commentators in the field, Dr. E. Fuller Torrey and attorney Mary Zdanowicz, a pattern of violence among the mentally ill is the result of deinstitutionalization "gone awry:"

The emerging pattern of violence is clear. And it is part of a larger pattern: increasing numbers of severely mentally ill individuals among the homeless population, incarcerated in jails and prisons for offenses

23 See THE PRESIDENT's COMM'N ON MENTAL HEALTH, REPORT tO the PREsident FROM THE PRESIDENT'S COMMISSION ON MENTAL HEALTH 44 (1978) (stating that the objective of the least restrictive alternative doctrine is to "maintain[] the greatest degree of freedom, self-determination, autonomy, dignity, and integrity of body, mind, and spirit for the individual while he or she participates in treatment or receives services"). For cases interpreting this concept, see Rogers v. Okin, 634 F.2d 650, 655-56 (5th Cir. 1980) (requiring the possibility and type of violence, the likely effects of the drugs on the individual, and the possibility of less restrictive alternatives to be balanced before anti-psychotic drugs can be forcibly administered); Covington v. Harris, 419 F.2d 617 (D.C. Cir. 1969) (identifying the maximum security ward as the most restrictive treatment setting in a hospital); Lake v. Cameron, 364 F.2d 657 (D.C. Cir. 1966) (en banc) (considering the location of treatment); Stamus v. Leonhardt, 414 F. Supp. 439, 462 (S.D. Iowa 1976) (holding full-time hospitalization to be more restrictive than use of outpatient facilities); Lessard v. Schmidt, 349 F. Supp. 1078, 1096 (E.D. Wis. 1972) (finding community treatment programs less restrictive than institutionalization); In re Farrow, 255 S.E. 2d 777, 781-82 (N.C. Ct. App. 1979) (stating that involuntary commitment is more restrictive than voluntary commitment). Treatment must be appropriate and effective for the patient, however, and the least restrictive alternative may not always be best. See, e.g., Leona L. Bachrach, Is the Least Restrictive Environment Always the Best? Sociological and Semantic Implications, 31 HOSP. \& COMMUNITY PSYCHLATRY 97, 100 (1980) (defining restrictiveness as not necessarily correlated with the degree of independent living, but rather dependent upon various environmental factors, such as location, degree of autonomy, and treatment provided); Thomas G. Gutheil et al., The Inappropriateness of "Least Restrictive Alternative" Analysis for Involuntary Procedures with the Institutionalized Mentally Ill, $11 \mathrm{~J}$. PSYCHIATRY \& L. 7, 12 (1983) (urging consideration of the effectiveness of the alternatives in determining which are least restrictive in a particular case). Kendra's Law requires that AOT be the least restrictive alternative. See Kendra's Law: The Process for Obtaining Assisted Outpatient Treatment, OMH Q., Dec. 1999, at 4, 6 [hereinafter Kendra's Law: The Process].

24 See Jilliane T. Hinds, Involuntary Outpatient Commitment for the Chronically Mentally $I l, 69$ NEB. L. REV. 346,347 (1990).

25. Id. at 349 (citation omitted). 
committed while psychotic, and loitering in parks, public libraries and transportation stations. The pattern is the product of deinstitutionalization gone awry, the discharge of hundreds of thousands of mentally ill individuals from the nation's public psychiatric hospitals without ensuring that they' get the medication they need to remain well. ${ }^{26}$

This pattern of violence is real. By one estimate, mentally ill people commit about 1000 homicides a year, or about $5 \%$ of total national homicides annually. ${ }^{27}$ Furthermore, about $20 \%$ of the 2.3 million adult Americans who suffer from bipolar disorder, also known as manic depression, and about $10 \%$ of the 2 million adult American schizophrenics commit suicide each year. ${ }^{28}$ States have responded to this crisis in one of three ways-conditional release, outpatient commitment as a dispositional alternative, and preventive commitment. ${ }^{29}$

\section{B. Legal Foundation for Deinstitutionalization and Outpatient Commitment}

States derive their authority to order outpatient commitment from the police power or from the parens patriae power. ${ }^{30}$ The police power justification rests on the theory that the State may enact laws to protect the public health, safety, and general welfare. ${ }^{31}$ The parens patriae

"E. Fuller Torrey \& Mary Zdanowicz, Thy Deinstitutionalization Tumed Deadly, W.ILL ST.J., Aug. 4,1998 , at A18.

"John Gibeaut, Who Knows Best?, A.B.A. J., Jan. 2000, at 49, 52.

Id. at 50 .

"Si Gerry McCafferty \& Jeanne Dooley, Involuntary Outpatient Commitment: An Update 14 MENTAL \& PHYSICAL DISABILITY L. REP. 277, 279-282 (1990) (stating that many states have incorporated one or more of these three responses into their statutes). Under conditional release, the treatment facility or the attending physician generally establishes the terms of release from the hospital, and failure to comply may result in rehospitalization. See id. at 279 (outlining the general provisions of conditional release programs). "[O]utpatient commitment as a [dispositional alternative is a] less restrictive alternative to hospitalization[] [a]fter a finding of mental illness and dangerousness to self or others...." Id. at 279-80 (footnote omitted). Under preventive commitment, "courts have the ... [discretion] to commit an individual who is not currently dangerous, but who ... [may become] dangerous without treatment." $I d$. at 281. Another mechanism that is used is conservatorship-guardianship, whereby a third party appointed by the court is given authority to consent to outpatient treatment on behalf of the patient, based on the notion of substituted consent. See Torrey \& Kaplan, suffra note 12, at 779 (comparing conservator-guardianship with outpatient commitment programs); see also infra Part I.C. (discussing various states' approaches). ed. 1985).

See SaMUEL JAN BRAKEL eT aL., THE MENTALly DiSABLEd AND THE LAW 24 (3d

To commit the noncriminal mentally ill under the police power, most states require a showing by clear and convincing proof that, as a result of the individual's mental illness: (1) the individual is unable to comply with the law or conform to the limits 
rationale empowers the State to protect those who cannot protect themselves. ${ }^{32}$ Often the State's intervention is an extension of the police power or the parens patriae power because it is exercised in anticipation of future harm, rather than in response to an "immediate threat to life or property." 33 This is true of Kendra's Law, which provides for AOT even if no act of violence has occurred, but where there is a likelihood of such an act occurring. ${ }^{34}$

Although the realm of mental health care is left to the states, the Constitution and the Supreme Court provide a minimal level of protection to the mentally ill. In 1975, the Court addressed the due process limitations on a state's power to civilly commit a person in O'Connor v. Donaldson. ${ }^{35}$ In Donaldson, the Court held that there is no constitutional basis to civilly commit a person if she is not dangerous

of social tolerance; (2) the individual does not appreciate the deterrent force of the law; and (3) as measured by magnitude and probability of harm, the individual is therefore potentially dangerous. $C f$. $i d$. at $24-25$ (discussing the parameters of what type of behavior may be considered to threaten the general welfare).

${ }^{32}$ To commit the noncriminal mentally ill under the parens patriae power, most states require a showing by clear and convincing proof that: (1) the individual, due to severe mental illness, is incompetent to make decisions regarding her condition and is therefore unable to seek appropriate treatment; and (2) the deprivation of liberty is warranted because the potential of harm to the patient is so great. Cf. id. at 24 (striking a balance between the liberty interest of the ward, her expressed wishes, and the care that a state may provide). Additionally, Black's Law Dictionary defines parens patriae as the

role of state as sovereign and guardian of persons under legal disability, such as juveniles or the insane.... It is the principle that the state must care for those who cannot take care of themselves, such as minors who lack proper care and custody from their parents. It is a concept of standing utilized to protect those quasi-sovereign interests such as health, comfort and welfare of the people, interstate water rights, general economy of the state, etc.

BLACK's LAW DICTIONARY 1114 (6th ed. 1990). The parens patriae power allows a state to act as "the general guardian of all infants, idiots, and lunatics." 3 WILLIAM BLACKSTONE, COMMENTARIES *47.

${ }^{33}$ Wilkinson, supra note 19 , at 1336 (quoting NICHOLAS N. KITTRIE, THE RIGHT TO BE DIFFERENT: DEVIANCE AND ENFORCED THERAPY 76 (1971)).

${ }^{34}$ A patient may satisfy the Kendra's Law criteria by making a threat or attempt at violence, even if no such violence occurs, or if the patient has merely been hospitalized for noncompliance with treatment. See N.Y. MENTAL HYG. LAW \$ 9.60(c)(4) (McKinney Supp. 2001).

35422 U.S. 563 (1975). The respondent, Donaldson, developed paranoid delusions that he was being poisoned and, at his father's instigation, was civilly committed to a Florida mental hospital for fifteen years. Id. at 564-65. During his commitment, Donaldson denied that he was ill and refused all treatment. Id. at 565 . He claimed that he was deprived of his constitutional right to liberty when his requests for release were denied. Id. These requests had been supported by alternative options for treatment. Id. at 567-68. 
to others and is capable of surviving safely in freedom..$^{36}$ Although this case arose in the context of involuntary inpatient mental health treatment, the issue of outpatient treatment was implicated in Chief Justice Burger's concurring opinion, in which he stated that the parens patriae power can be exercised over a ward in ways other than substantially restraining him. ${ }^{37}$ He went on to state:

$[H]$ owever the [parens patriae] power is implemented, due process requires that it not be invoked indiscriminately. At a minimum, a particular scheme for protection for the mentally ill must rest upon a legislative determination that it is compatible with the best interests of the affected class and that its members are unable to act for themselves. ${ }^{38}$

This language from Donaldson suggests that a state may justify its use of the parens patriae power in ordering involuntary outpatient treatment only if it first determines that such treatment is in the patient's best interest and that the patient lacks the capacity to decide whether to seek such treatment. Under this standard, it is important to recognize that mental illness does not necessarily imply incompetence. ${ }^{39}$ Kendra's Law does not identify impaired decisionmaking ability as a prerequisite to administering involuntary outpatient treatment. ${ }^{10}$

While the Donaldson decision appears to limit the states' power to order AOT, one prominent commentator in the field, Paul F. Stavis, believes that the Court did not intend to encumber the states' traditional authority to care for the incompetent:

But since the Court has never before contradicted the power of the state to care for those who are incompetent to make decisions, e.g., children, as well as incompetent mentally retarded and mentally ill persons, but rather has said it is inherent in the power of the government, it is questionable that the Supreme Court in the Donaldson decision intended to eliminate or even unduly encumber this traditional power of the state, it has caused undue confusion and impairment of the state's ability to act

${ }^{3 t}$ See id. at 576 ("[A] State cannot constitutionally confine without more a nondangerous individual who is capable of surviving in freedom by himself or with the help of willing and responsible family members and friends.").

${ }^{37}$ Id. at 583 (Burger, C.J., concurring). Other ways in which the parens patriae power may be exercised include appointing a guardian to control the ward's property or placing the ward in the custody of a private third party. Id.

is Id.

"See, e.g., David B. Wexler, Mental Health Law: Major Issues 40 (1981) ("'[M] any persons who are mentally ill are entirely competent to make rational and important decisions concerning their affairs, including the decision to accept or reject hospital treatment." (quoting Bruce J. Ennis, Civil Liberties and Mental Illness, 7 CRIM. L. BULL. 101, 104 (1971))).

I" N.Y. MENTAL HYG. LAW \$ 9.60(c) (McKinney Supp. 2001). 
appropriately and swiftly. ${ }^{41}$

Consistent with Stavis's theory, and despite the Court's apparent attempt to provide minimal protections to the mentally ill and limit the states' power to civilly commit them, the trend has been towards expansion of the parens patriae power. In 1983, the American Psychiatric Association ("APA") promulgated its Model Law for Civil Commitment. ${ }^{42}$ The APA's Model Law provides for commitment of those who are "likely to suffer substantial mental or physical deterioration," which has the effect of "[s]ignificantly ... expand[ing] current parens patriae commitment [power to reach] ... many of those severely mentally ill people who... roam the streets aimlessly and without hope." ${ }^{\prime 4}$ Under this standard, the court is not required to find danger or harm. Such an expansion of power accords with the conventional understanding of the justifications for parens patriae. Consistent with the APA's suggestion, many states have incorporated either a "passive harm" (deterioration) standard or a "gravely disabled" or "unable to provide for basic needs" standard into their civil commitment laws." Kendra's Law has incorporated the deterioration standard into law. It does so by providing for outpatient treatment if it is needed to "prevent a relapse or deterioration which would be likely to result in serious harm to the patient or others."

Thus, it appears that the states have strayed from the police power justification for civil commitment-as that justification implies that there is a need to protect the public from danger. There is no such need, however, if the "dangerousness" standard is not incorporated into the law. The mere fact that one has deteriorated or is unable to provide for basic needs is not a sufficient rationale by which the State may claim that the public health, safety, and general welfare are threatened. Therefore, the parens patriae power is a more plausible foundation for the states' commitment power, given that they will exercise this power if the patient is a danger to himself (even in a passive sense, by not seeking necessary treatment) and lacks the capacity to

${ }^{41}$ Paul F. Stavis, Civil Commitment: Past, Present, and Future, Address at the National Conference of the National Alliance for the Mentally Ill (July 21, 1995), at http://www.psychlaws.org/LegalResources/articles/LawArticle2.htm.

${ }^{42}$ Klapper, supra note 22, at 754 .

I3 $I d$. at 754 n.32.

44. at 754-55.

See infra notes 54,56-57 and accompanying text (providing examples of such statutes).

${ }^{46}$ N.Y. MENTAL HYG. LAW $\$ 9.60$ (c) (6) (McKinney Supp. 2001) (emphasis added). 
make a reasoned decision about whether or not to seek treatment, as was the situation in Donaldson. ${ }^{47}$

\section{States'Approaches to Outpatient Commitment}

\section{Sources of Authority and Standards for AOT}

With the passage of Kendra's Law in 1999, New York joined forty other states and the District of Columbia in providing outpatient commitment to people suffering from mental illnesses. ${ }^{48}$ Prior to 1994, New York was the only state that had a statute specifically prohibiting outpatient commitment. ${ }^{47}$ In 1994, legislation was passed permitting the Bellevue Pilot Program." Subsequently, Kendra's Law took effect on November 8, 1999.

Of the forty states that provide for AOT, only ten (including New York) specify different criteria for inpatient and outpatient commitment. "In these states, the standards for inpatient commitment are more stringent, presumably due to the increased restraint on liberty involved with inpatient treatment. ${ }^{52}$ In addition, the creation of a dif-

Supra text accompanying note 38.

"Jennifer Gutterman, Note, Waging a War an Drugs: Administering a Lethal Dose to Kendra's Lau', 68 FordHAM L. REv. 2401, 2408 (2000). Currently, only California, Connecticut, Florida, Maine, Maryland, Massachusetts, Nevada, New Jersey, and New Mexico do not have AOT laws. Nat'l Conference of State Legislatures, Fact Sheet: Outpatient Civil Commitment (July 14, 1999), at http://www.ncsl.org/programs/health/ hpts/commit.htm.

" Torrey \& Kaplan, supra note 12, at 781-82.

N.I N. MENTAL HYG. LAw \$ 9.61(b) (McKinney 1996) (renumbered \$ 9.63 by 1999 N.Y. Laws $408, \S 9$ ). A study of the pilot program at Bellevue Hospital revealed that those who participated spent fifty-seven percent less time in the hospital than those who did not participate. Press Release, D.J. Jaffe, N.Y. Coordinator, N.Y. Treatment Adrocacy Coalition, New York Stands at Crossroads of Success or Failure: NYS Must Expand Outpatient Commitment Statewide for Individuals with Severe Psychiatric Illnesses (Jan. 28, 1999), at http://www.psychlaws.org/PressRoom/ stmt-dj\%20NY\%20AG.htm.

ALl. CODE $\$ 22-52-10.3$ (1997); ALASKA STAT. \$ 47.30.795 (Michie 2000); GA. CODE ANN. \$ 37-3-1 (12.1) (1995); HAW. REV. STAT. \$ 334-121 (1993); IND. CODE ANN. $\$ 12-26-14-1$ (West 1994); N.Y. MENTAL HYG. LAW \$ 9.60(c) (McKinney Supp. 2001); N.C. GEN. STAT. \$ 122C-267(h) (1999); TEX. HEALTH \& SAFETY CODE ANN. \$ 574.034 (Vernon Supp. 2001); VA. CODE ANN. $\$ 37.1-67.3$ (Michie Supp. 2000); WASH. REV. CODE ANN. \$ 71.05.240 (West Supp. 2001).

5.2 For example, in the Alabama statutes, ALA. CODE $\$ 22-52-10.3$ to -10.4 (1997), the criteria for inpatient and outpatient commitment are virtually the same, except that for inpatient treatment there is the additional requirement that "as a result of the mental illness the respondent poses a real and present threat of substantial harm to self and/or others," $i d . \$ 22-52-10.4$ (a) (ii). 
ferent standard for outpatient commitment allows the state to reach persons uncommittable under the inpatient statute.

Several states have adopted the APA's "passive harm" or deterioration standard into their civil commitment laws, ${ }^{54}$ thereby exercising their police and parens patriae powers to the outermost limits. ${ }^{5.5}$ New York is among the fourteen states whose laws fall within this category." Most states, but not New York, have also incorporated a "gravely disabled" or "unable to provide for basic needs" standard, which also extends the parens patriae authority to "passive harms."

\section{States' Utilization of and Success with Outpatient Commitment}

State laws that allow for intervention before the patient poses a risk of current danger are known as "preventive commitment." The targets of preventive commitment statutes are "revolving door" patients-patients who, as a consequence of medication noncompliance,

${ }^{53}$ For example, Washington's statute for inpatient and outpatient commitment differs only by whether a more or less restrictive alternative is in the best interest of the patient. WASH. REV. CODE ANN. $\$ 71.05 .240$ (West Supp. 2001). If a more restrictive treatment is in the best interest of the patient, then inpatient treatment is authorized; if a less restrictive course of treatment is in the best interest of the patient, then outpatient treatment is authorized. Id.

${ }^{54}$ See, e.g., ALA. CODE $\$ 22-52-10.2$ (ii) (1997) (describing as civilly commitable one who has, as a result of the mental illness, "experience[d] deterioration of the ability to function independently"); OR. REv. STAT. $\$ 426.005$ (1) (d) (C) (iv) (Supp. 1998) (defining a "[m]entally ill person" as one who "[u]nless treated, will continue ... to physically or mentally deteriorate so that that the person will be [dangerous to self or others, or unable to provide for basic personal needs]"); VT. STAT. ANN. tit. 18, $\$ 7101$ (16) (B) (1987) (defining "[a] patient in need of further treatment" as one who "is receiving adequate treatment, and who, if such treatment is discontinued, presents a substantial probability that in the near future his condition will deteriorate").

${ }^{55}$ See supra Part I.B (explaining the legal foundation for deinstitutionalization and outpatient commitment).

${ }^{36}$ N.Y. MENTAL HYG. LAW $\$ 9.60$ (c) (6) (McKinney Supp. 2001) (noting that a patient may need AOT "in order to prevent a relapse or deterioration which would be likely to result in serious harm to the patient or others").

57 See, e.g., HAW. REV. STAT. \$ 3341 (1993) (employing a "gravely disabled" standard); MICH. COMP. LAWS ANN. $\$ 330.1401$ (b) (West 1999) (defining a "person requiring treatment" as "[a]n individual who... as a result of ... mental illness is unable to attend to those of his or her basic physical needs such as food, clothing, or shelter"); VA. CODE ANN. \$ 37.1-67.3 (Michie Supp. 2000) (providing that a person can be committed if he is "so severely mentally ill as to be substantially unable to care for himself").

See McCafferty \& Dooley, supra note 29 (describing states' use of involuntary outpatient commitment). 
are repeatedly released and rehospitalized. ${ }^{59}$ North Carolina has been widely recognized as the leader in implementing preventive commitment." Studies of outpatient commitment in North Carolina were undertaken by Hiday and Scheid-Cook, who found that both hospital admissions and length of hospital stays were reduced for patients participating in outpatient commitment. ${ }^{61}$ Such success was found to turn on staff dedication, rather than on coercion. ${ }^{62}$ In fact, North Carolina's statute minimizes compulsion and prohibits forced medication, except in the event of an emergency. ${ }^{63}$ Hawaii's statute similarly prevents such coercion. ${ }^{6}$ In both North Carolina and Hawaii, if the patient refuses to comply, the only remaining alternative is rehospitalization. Critics condemn this lack of meaningful enforcement mechanisms and believe that "[p]reventive commitment... works merely as a form of judicial intimidation. Compliance is achieved only if the person fears rehospitalization or mistakenly believes that the court's order must be obeyed." In contrast, Georgia's outpatient commitment statute authorizes forced medication as the solution to enforcement difficulties. ${ }^{67}$

Despite this claimed success in North Carolina, the Hiday and Scheid-Cook study also found that about half of those ordered to outpatient commitment were not appropriate candidates for such commitment because they had no prior history of hospitalizations, no indications of prior dangerousness, and no prior history of medication refusal." This finding provides grounds for a constitutional challenge

Torrey \& Kaplan, supra note 12, at 779.

Ronald L. Wisor Jr., Community Care, Competition and Coercion: A Legal Perspective on Privatized Mental Health Care, 19 AM. J.L. \& MED. 145, 166 (1993).

${ }^{11}$ Sie Virginia Aldige Hiday \& Teresa L. Scheid-Cook, The North Carolina Experience with Outpatient Commitment: A Critical Appraisal, 10 INT'L J.L. \& PSYCHIATRY 215, 232 (1987) (noting this result as a response to state statutory revisions tightening the criteria for involuntary hospitalization and giving due process to respondents of civil commitment petitions).

${ }^{12}$ See id. at 230 (finding that in the most successful community programs, the staff did whatever was necessary to keep patients in the community, including supplying transportation, jobs, schooling, recreation, child care, money for medication, adequate housing, and training opportunities).

".6 N.C. GEN. STAT. \$122C-273(a) (3) (1999). The physician may try to persuade a noncompliant patient and make any "reasonable effort" to gain compliance, but may not forcibly administer medication. Id. \$122C-273(a) (2).

$"$ HAW. REV. STAT. \$ 334-129(b) (1993).

$\therefore$ Id. $\$ 334-129$ (c); N.C. GEN. STAT. \$ 122C-273(a) (2) (1999).

"." Wisor, supra note 60 , at 171 .

i. G. CODE ANN. \$ 37-3-82(b) (1995).

1.* Hiday \& Scheid-Cook, supra note 61, at 222. 
that the statute is overinclusive and not rationally related to the State's objectives. ${ }^{69}$ To avoid this problem, an outpatient commitment statute should be drafted to require demonstrated histories of rehospitalization, a persistent pattern of noncompliance in the community, and deterioration to dangerousness. ${ }^{70}$ The current criteria for Kendra's Law does include such requirements, making it more constitutionally sound than North Carolina's statute. ${ }^{71}$

Other studies of outpatient commitment have been performed in the District of Columbia, Arizona, and Tennessee. ${ }^{72}$ In the District of Columbia, a study revealed that outpatient commitment reduced hospital readmissions by half and shortened inpatient stays. ${ }^{73}$ In Arizona, a study found that outpatient commitment kept patients in treatment longer, shortened inpatient stays, and possibly reduced violent episodes. ${ }^{74}$ However, Bursten's study of outpatient treatment in Tennessee revealed that it had no effect on readmission rates over a fourteenmonth period. ${ }^{75}$

In a survey undertaken by Torrey and Kaplan in 1994, only thirteen states and the District of Columbia commonly utilized outpatient commitment. ${ }^{76}$ The thirteen states characterized the use of outpatient commitment as rare, citing reasons that Torrey and Kaplan organize into eight groups. ${ }^{77}$ First, mental health professionals voiced concerns about civil liberties and expressed a dedication to increasing individual autonomy. ${ }^{78}$ Second, mental health professionals were concerned

${ }^{69}$ See Wisor, supra note 60 , at 169.

${ }^{70} \mathrm{Id}$

${ }^{71}$ See N.Y. MENTAL HyG. LAW $\$ 9.60$ (c) (4) (i) (McKinney Supp. 2001) (requiring a history of lack of compliance with treatment that has resulted in hospitalization at least twice within the last three years); see also infra note 175 (referring to the requirements of the New York statute).

${ }^{72}$ Torrey \& Kaplan, supra note 12 , at 779.

${ }^{73}$ Id. (citing Guido Zanni \& Leslie deVeau, Inpatient Stays Before and After Outpatient Commitment, 37 HOSP. \& COMMUNITY PSYCHLATRY 941 (1986); D. Band et al., Outpatient Commitment: A 13-year Experience, ST. ElIZABETHS HOSP. CONTINUING MED. EDUC. NEwSL. (St. Elizabeths Hosp., D.C.), Dec. 1984, at 1).

${ }^{74}$ Id. (citing Robert A. Van Putten et al., Involuntary Outpatient Commitment in Arizona: A Retrospective Study, 39 HOSP. \& COMMUNITY PSYCHIATRY 953 (1988)).

${ }_{75}$ Ben Bursten, Posthospital Mandatory Outpatient Treatment, 143 AM. J. PsYCHIATRY 1255,1257 (1986) ("[T] he data do not support the effectiveness of the law [of involuntary outpatient commitment].”). Torrey and Kaplan speculate, however, that this lack of success may be due to failure to vigorously enforce the law. Torrey \& Kaplan, supra note 12 , at 779 .

\footnotetext{
${ }^{76}$ Torrey \& Kaplan, supra note 12 , at 782.

${ }^{77}$ Id.

78 Id.
} 
about liability if outpatients under their supervision committed crimes. $^{74}$ Third, some mental health centers had a relative lack of interest in treating mentally ill individuals. ${ }^{80}$ Fourth, some states noted that outpatient commitment imposes a fiscal burden on mental health centers because of the need to hire additional staff to monitor compliance. ${ }^{\text {Il }}$ In a few states, inpatients were the fiscal responsibility of the state, but outpatient commitments were the fiscal responsibility of the counties, which created a further disincentive to use outpatient commitment. ${ }^{\wedge 2}$ Fifth, some states were concerned that noncompliance with outpatient commitment would lead to increased demand for hospital beds. ${ }^{\text {sy }}$ Sixth, states with more stringent commitment criteria were less likely to use outpatient commitment. ${ }^{84}$ In contrast, states with less restrictive criteria, such as the "gravely disabled" or "unable to provide for basic needs" standard were more likely to use outpatient commitment. ${ }^{85}$ Seventh, the lack of consequences for patients who fail to comply with a treatment plan have deterred some states from using outpatient commitment. ${ }^{86}$ States that permit involuntary medication, however, have made more use of outpatient commitment. ${ }^{\times 7}$ States that do not permit involuntary medication have found that the process of rehospitalizing an outpatient is both cumbersome and time-consuming. ${ }^{\$ \$}$ Finally, the authors found "a lack of awareness and knowledge about outpatient commitment" among state officials, mental health centers, consumers, and families. ${ }^{89}$

Such collateral concerns result in the wide underutilization of outpatient commitment. Legislation authorizing outpatient commitment is not sufficient to promote its use without addressing the above concerns. Some states have turned from outpatient commitment to other alternatives, such as conditional release. In New Hampshire, for

It Id

$\$ 1 d$.

"I $I d$.

Id.

"Id. As Torrey and Kaplan note, however, prior studies of outpatient commitment suggest a decrease in hospitalization. $I d$.

Id.

$\therefore$ Id.; ste also supra notes 54,57 (providing examples of state statutes that utilize such criteria).

"Torrey \& Kaplan, supra note 12, at 782.

${ }^{\prime 7}$ St $t$ id. (noting how outpatient commitment programs that allow for built-in consequences are used regularly in some states that allow involuntary medication).

Id. at 783 .

Id. 
example, conditional release is preferred to outpatient commitment. ${ }^{i n t}$ In California, conservatorship-guardianship is often used, though it is not frequently used in other states where it is available, such as Massachusetts and New Mexico. ${ }^{91}$ Other states have developed informal mechanisms for achieving voluntary compliance with medication, such as "suspend[ing] an inpatient commitment hearing on the condition that the individual undergo voluntary outpatient treatment." Rhode Island, Virginia, and Vermont have found that "judicial wrath,' [or] a stern lecture by a judge on the necessity of treatment, is sometimes effective" in securing compliance..$^{93}$ Also, "the threat of inpatient commitment [is] occasionally used to compel outpatient compliance."

Despite these alternatives, outpatient commitment statutes continue to exist in forty-one states. ${ }^{95}$ Outpatient commitment has not been utilized uniformly across the country, and it has met with varying degrees of success. North Carolina is considered to be the most successful in implementing outpatient commitment programs, yet the State's statute may be unconstitutionally overbroad. ${ }^{96}$ A statute authorizing outpatient commitment needs to be narrowly tailored to target the appropriate population and be rationally related to the State's goals of protecting society from harmful individuals and protecting affected individuals from themselves. Kendra's Law is New York's attempt to accomplish these objectives.

\section{Mechanics of Kendra's Law}

Under Kendra's Law a court may order a person to submit to AOT only if certain criteria are met. ${ }^{97}$ The statute provides specific procedures for the issuance of AOT orders, beginning with the filing of a

${ }^{90}$ Id. For an explanation of conditional release, see McCafferty \& Dooley, supra note 29 , at 279-81.

${ }^{91}$ Torrey \& Kaplan, supra note 12, at 780. Although conservatorship-guardianship is used in California, it is often used as a way of coercing compliance with outpatient commitment programs. Id. For an explanation of conservatorship-guardianship, see id. at 779 . ming).

${ }^{92} I d$. at 780 (noting that this practice is prevalent in Kentucky, Oregon, and Wyo-

Id. at 781 .

${ }^{94} I d$.

${ }^{95}$ Supra note 48 and accompanying text.

See supra Part I.C.2 (describing the different state programs and their success).

${ }^{97}$ See N.Y. MENTAL HYG. LAw \$ 9.60(c) (McKinney Supp. 2001) (detailing the requirements for court-ordered AOT). 
petition in the supreme or county court. "The petition is a formal statement of facts demonstrating that the person meets the criteria for AOT." Only individuals with particular relationships to the potential outpatient may file a petition on behalf of someone thought to be in need of AOT. ${ }^{\text {ine }}$ The locality's mental health director is not required "to file petitions at the request of other parties," but she is required to "investigate reports of individuals alleged to be in need of AOT." addition, the petition must be supported by the affidavit of a physician who has examined the patient within the last ten days, stating that the individual meets the criteria for AOT. ${ }^{102}$ Alternatively, the physician may state that she was unable to obtain the patient's consent to conduct an examination in the past ten days but has reason to believe that AOT is warranted." "In both cases, the physician must be willing to testify at the court hearing." ${ }^{101}$ The petition must be served not only on the subject, but also on "the subject's nearest known relative; Mental Hygiene Legal Services (MHLS); any health care agent appointed by the person in a health care proxy ... ; the [AOT] program coordinator appointed by [the Office of Mental Health] ...; and the appropriate $[\mathrm{AOT}]$ mental health director." 105 The court is required to set a hearing date no more than three days after the petition for AOT is filed, although adjournments can be granted for good cause. ${ }^{106} \mathrm{No}-$ tice of the hearing is given to all parties who received notice of the petition. ${ }^{117}$

Various procedural protections are granted to the subject of the

"*indra's Law: The Process, supra note 23, at 4.

"Id.

${ }^{11 *}$ The following individuals may file a petition:

an adult roommate ...; ; a parent, spouse, adult child or adult sibling . . .; the director of a hospital where the recipient is hospitalized; the director of a public or charitable organization, agency, or home that provides mental health services to the recipient and in whose institution the recipient resides; a [qualified] psychiatrist who is either treating the recipient or supervising the recipient's treatment for mental illness; the director of community services... or social services official of the city or county where the recipient is present or believed to be present; or a parole officer or probation officer assigned to superise the recipient.

Id.

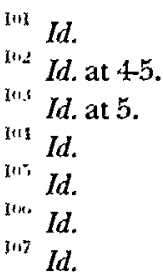


petition. "The subject... is entitled to legal representation from MHLS or a private attorney at all stages of the proceeding" and is "afforded an opportunity to present evidence, to call witnesses and to cross-examine adverse witnesses." ${ }^{108}$ The court may consider any admissible evidence, including testimony from the petitioner or from the subject (if she chooses to testify). ${ }^{109}$ The court must consider the testimony of the examining physician who filed the affidavit with the petition. ${ }^{110}$ The physician must state "the facts and rationale supporting the need for AOT." Most importantly, the physician must support the conclusion "that AOT is the least restrictive alternative of treatment."112 At this time, the court may order the patient to submit to an examination by a court-appointed physician if she had refused to be examined at the time the petition was filed. ${ }^{113}$ If the court believes the allegations in the petition to be true and the subject continues to resist examination, the court may order law enforcement officials to take the subject to a hospital for an examination for the purpose of determining whether the criteria for AOT are met. ${ }^{114}$ The patient may not be retained at the hospital, however, for more than twenty-four hours. ${ }^{115}$

A proposed written plan for treatment developed by the examining physician must be submitted to the court before AOT will be ordered. $^{116}$ The patient, the patient's treating physician, relative, close friend, or other concerned individual may actively participate in the development of the treatment plan. ${ }^{117}$ The plan must utilize case management services or assertive community treatment ("ACT") teams to coordinate care and may also include therapy, medication,

${ }^{108} I d$.
${ }^{109} I d$.
${ }^{110} I d$.
${ }^{111} I d$.
${ }^{112} I d$. (emphasis added).
${ }_{113} I d$.
${ }_{114} I d$.; see also In re Dir. of Cmty. Servs., 715 N.Y.S.2d 833 (N.Y. Sup. Ct. 2000) (holding that the statute does not implicitly require a hearing to determine whether there is reasonable cause to believe that the allegations in the petition are true before the patient is taken into custody for a physical examination).

${ }_{15}$ Kendra's Law: The Process, supra note 23, at 5.

${ }^{116}$ Id. The plan must be submitted to the court within three business days of the hearing, but if the petitioner is a mental health director or a director of an AOT program, then the plan is to be provided to the court by the date of the hearing. Id.

${ }^{117}$ See Office of Counsel, N.Y. State Office of Mental Health, Summan-An Explanation of Kendra's Law, at http://www.omh.state.ny.us/omhweb/Kendra_web/ Ksummary.htm (last visited Nov. 14, 2000). 
substance-abuse counseling and treatment, educational and/or vocational activities, and supervision of living arrangements. ${ }^{118}$ If medication is proposed as part of the plan, the doctor must testify as to the types of medication recommended and "dosage ranges, the beneficial as well as detrimental physical and mental effects of the medication(s), and ... whether the medications should be self-administered or administered by authorized personnel."119 In addition, if medication is recommended, the plan may include compliance monitoring, such as periodic blood tests or urinalysis. ${ }^{120}$ Alcohol or illegal substances testing may also be included if the plan provides for alcohol or substance abuse counseling. ${ }^{121}$ Testing may only be included, however, if the patient "has a history of alcohol or substance abuse which is clinically related to his or her mental illness, and the testing is necessary to prevent a relapse or deterioration which would be likely to result in serious harm to the self or others." must be reviewed after six months by a physician, who may then terminate the testing. ${ }^{123}$

Finally, the court will issue an order for AOT if, "after hearing all relevant evidence..., the court finds by clear and convincing evidence that the subject... meets the criteria for AOT and that [AOT] is the least restrictive appropriate treatment." final AOT order, the court will also consider any directives that may have been executed by the subject in a health care proxy. ${ }^{125}$ "If . . the court concludes that all the criteria for AOT are not met, the petition must be dismissed." 126 If an order for AOT is rendered, it is effective for six months and may be extended in one-year periods, so long as the subject continues to meet all of the AOT criteria. " "[T] he order is directed to both the person receiving AOT and also to the local director of the AOT program."

Iix Kindra's Law: The Process, supra note 23, at 5-6.

II" $I$. at 6 .

rin' It.

In.

Ii: $I$ at $6-7$.

1.2.5. at 7 .

34 In. at 6 . For a discussion of the least restrictive alternative doctrine, see also $s u$ pronote 23.

12: Kendra's Law: The Process, supra note 23, at 7.

1." Id. at 6 .

${ }^{127} I d$. at 7 .

IR: Id. at 6 . 
ment and the local AOT director must furnish the treatment.

Once an AOT order has been issued by the court, the New York State Office of Mental Health ("OMH") is required to monitor and report all noncompliance. ${ }^{130}$ A case manager or ACT team will coordinate the provision of all court-ordered services and closely monitor the patient's progress. ${ }^{\mathrm{i} 31}$ The case manager or ACT team will also report all noncompliance to the county or City of New York mental health director. ${ }^{132}$ However, medication "may not be administered over the individual's objection." sician may recommend that the patient be taken to a hospital and be retained there for up to seventy-two hours to determine if a need exists for inpatient treatment. ${ }^{134}$ Noncompliance may be a factor in determining involuntary admission. ${ }^{135}$ Mandatory quarterly reports must be submitted to the OMH Program Coordinator for additional oversight. $^{13 \dot{0}}$

\section{EVAluAtion OF NEW York's STATUTORY PROVISIONS FOR AOT}

\section{A. Federal Constitutional Analysis}

\section{Substantive Due Process}

The Due Process Clause of the Fourteenth Amendment provides that " $[\mathrm{n}]$ o State ... shall deprive any person of life, liberty, or property, without due process of law." ${ }^{137}$ The courts have used the Due Process Clause to protect substantive as well as procedural rights. ${ }^{13 *}$ In

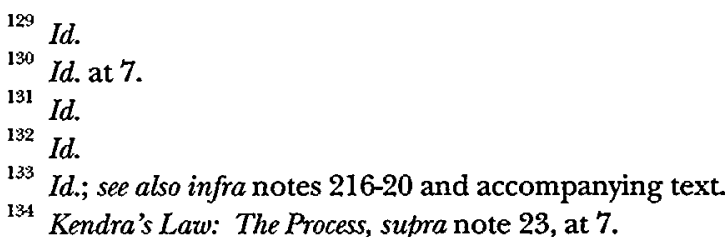

${ }^{135}$ A recipient's failure to comply with an order for AOT is not grounds for involuntary civil commitment or contempt of court. However, any refusal of the individual to take prescribed medication, or the failure of a test to determine either medication compliance or alcohol or drug use, may be considered by the physician in reaching a clinical determination regarding involuntary admission.

Id.

${ }^{136} I d$

${ }^{137}$ U.S. CONST. amend. XIV, $\$ 1$.

${ }^{138}$ See United States v. Carolene Prods. Co., 304 U.S. 144, 152 n.4 (1938) (providing for strict scrutiny of noneconomic political and social rights); Lochner v. New York, 198 U.S. 45, 64-65 (1905) (providing substantive due process protection for the 
considering substantive due process, the courts have developed a three-prong analysis, evaluating: (1) the compelling nature of the government's objective; (2) the liberty interests sacrificed in furthering the government's objective; and (3) whether the means and ends are rationally related. ${ }^{139}$ The closeness of fit between means and ends implicates the least restrictive alternative doctrine in the context of mental health law. ${ }^{\text {(40 }}$

The least restrictive alternative doctrine requires that treatment be provided in the least restrictive feasible manner, in order to serve the dual objectives of preserving the individual's autonomy to the greatest extent possible while simultaneously ensuring public safety. If less restrictive yet appropriate alternatives to institutionalization exist, then the states would be obligated to consider them. Moreover, the doctrine mandates that the State provide community-based treatment as an option. With the passage of Kendra's Law, New York has provided a less restrictive option than institutionalization for the mentally ill. Kendra's Law specifically requires the examining physician to testify that assisted outpatient commitment is the least restrictive alternative course of treatment. ${ }^{141}$

Although New York requires that less restrictive alternatives be examined before a patient is committed to outpatient care, the State might not even be constitutionally required to provide such options. That issue has arisen in the context of an inpatient seeking less restrictive outpatient care. While the courts seemed receptive to the doctrine and the idea of mandatory community-based alternatives in Lake v. Cameron $^{142}$ in 1966 , by 1982 , the Supreme Court retreated from the concept in Youngberg $v$. Romeo. ${ }^{143}$ In Lake, a nondangerous mentally retarded woman asserted the right to have the court consider less restrictive alternatives before committing her to St. Elizabeths Hospital. ${ }^{11}$ The court ordered that the trial court make "an earnest effort...to review and exhaust available resources of the community." "The patient, however, was merely accorded an empty

economic right of freedom of contract).

"Se, e.g., Roe v. Wade, 410 U.S. 113, 155 (1973) (holding that a regulation limiting "fundamental rights" must be narrowly tailored to a "compelling state interest"); Griswold v. Connecticut, 381 U.S. 479, 485 (1965) (noting that such regulation may not sweep too broadly).

14:" See supra notes $22-23$ and accompanying text.

${ }^{141}$ N.Y. MENTAL. HYG. LAW $\$ 9.60(\mathrm{~h})$ (4) (McKinney Supp. 2001 ).

14. 364 F.2d 657 (D.C. Cir. 1966).

14. 457 U.S. 307 (1982).

i4 Lake, 364 F.2d at 659 .

in. In. at 660 . 
right because no less restrictive alternatives were available. The court did not decide whether the states would be obligated to provide community-based treatment should it not be available. ${ }^{146}$

In Youngberg, the patient was a mentally retarded man who was involuntarily confined at the Pennhurst mental institution. The patient claimed that his confinement violated his due process rights to safe conditions of confinement, freedom from bodily restraints, and the right to minimal training and development of basic skills. ${ }^{147}$ The Court accepted all three claims, characterizing them collectively as the constitutional right to "minimally adequate care and treatment" only where it was necessary to sustain liberty interests in safety and movement. ${ }^{148}$ The Court thus rejected the least restrictive alternative doctrine and gave deference to the judgment of mental health professionals in deciding what type of treatment and in what setting it is most appropriate. ${ }^{149}$

The Youngberg decision left uncertain whether a constitutional right to community-based treatment exists. Since Youngberg, courts have made its implications explicit—both in abandoning the least restrictive alternative doctrine and in insisting on deferring to professional judgment. For example, the Second Circuit, in Society for Good Will to Retarded Children, Inc. v. Cuomo, held that "there is no constitutional right to a least restrictive environment." Supreme Court, in the 1984 decision of Pennhurst State School $\mathcal{E}$ Hospital $v$. Halderman, ruled that federal judges cannot impose the obliga-

${ }^{140}$ Id. at 662 .

147 Youngberg, 457 U.S. at 315-17.

${ }^{148}$ Id. at 319 . The Court stated that "[a]s a general matter, a State is under no constitutional duty to provide substantive services for those within its border." Id. at 317 . The Court did recognize, however, a state's duty to care for those whose liberty it had restricted. See id. at 322 (imposing liability for "substantial departure[s] from accepted professional judgment, practice or standards" on the part of state institutional administrators).

${ }^{149}$ Id. at 319; see also Bruce A. Arrigo, The Logic of Identity and the Politics of Justice: Establishing a Right to Community-Based Treatment for the Institutionalized Mentally Disabled, 18 NEw ENG. J. ON CRIM. \& CIV. CONFINEMENT 1, 3 (1997) ("Not only did Youngberg dispense with 'the least intrusive means' doctrine,... but it substituted this standard by giving deference to accepted professional judgment that carried with it the presumption of validity.").

150 737 F.2d 1239, 1249 (2d Cir. 1984); see also Lelsz v. Kavanagh, 807 F.2d 1243. 1249 (5th Cir. 1987) (noting the district court's denial of the existence of such a constitutional right being at issue); Clark v. Cohen, 794 F.2d 79, 93 (3d Cir. 1986) (outlining the quid pro quo theory of commitment); Rennie v. Klein, 720 F.2d 266, 268-69 (3d Cir. 1983) (summarizing the Court's decision in Youngberg). 
tion to consider less restrictive alternatives on state officials. ${ }^{151}$ The Court interpreted the Eleventh Amendment as barring federal courts from ordering state officials to comply with state laws. ${ }^{152}$

In light of these Supreme Court and federal court decisions, most states have incorporated the least restrictive alternative doctrine into their commitment laws, although they are not constitutionally required to do so. Yet, this right to treatment in the least restrictive setting is theoretical, as many states' civil commitment laws require only that alternatives that are "available" be considered, whether or not what is available is appropriate. ${ }^{153}$

Although New York's outpatient law does not specify that only "available" alternatives be considered, ${ }^{154}$ it is unlikely that the courts will interpret Kendra's Law to constitutionally require the development of community-based alternatives, or even less restrictive alternatives, given the Society for Good Will opinion. ${ }^{155}$ In the aftermath of the Youngherg decision, it is logical to assume that there is likewise no constitutional right to less restrictive alternatives than community-based care. Although Kendra's Law provides an empty right to the least restrictive alternative course of treatment, it is not constitutionally deficient in this regard. In practice, Kendra's Law stipulates that the $\mathrm{OMH}$ must provide grants to counties to enable them to better track mentally ill people when they are discharged from psychiatric hospitals, state prisons, or county jails. Under the Medication Grant Program, the OMH must also help to furnish such patients with the psychiatric medications they need while they are applying for Medicaid. ${ }^{156}$ The 2001-2002 New York State Executive Budget provides these

465 U.S. 89 (1984).

$1: 2$ Id.

${ }^{1}$ S.1 See, e.g., KY. REv. STAT. ANN. \$ 202A.011(7) (Michie 1998); OHIO REv. CODE ANN. $\$$ 5122.15(E) (Anderson 1998); TEX. HEAlTH \& SAFETy CODE ANN. $\$ \$ 571.004(1), 576.021$ (1) (Vernon 1992); W. VA. CODE \$ 27-5-3(a) (1999).

Se N.Y. MENTAL HYG. LAW $\$ 9.60(\mathrm{~h})(4)$ (McKinney Supp. 2001) (noting that the treatment must be "the least restrictive alternative").

Ste Sur'y for Good Will, 737 F.2d at 1249 ("[T]here is no constitutional right to community placement ...."). at $3,3$.

"'t' Kendra's Law: New York's Assisted Outpatient Treatment Law, OMH Q., Dec. 1999,

Within amounts appropriated therefor, the commissioner of mental health shall provide grants to each county and the city of New York, which shall be used by each such county ur city, to provide medication, and other services necessary to prescribe an $\rfloor$ administer medication to treat mental illness during the pendency of a $\mathrm{m}$ edical assistance eligibility determination.

1999 N.Y. Laws $408, \$ 15$ ( $a^{\circ}$; see also infra note 243 and accompanying text (discussing the provisions of the Med: tation Grant Program). 
grants, which hopefully will be sufficient to carry out the objectives of Kendra's Law. ${ }^{157}$

Substantive due process concerns are also implicated by the patient's deprivation of a degree of liberty when she is forced to undergo any type of treatment, even if that treatment is in an outpatient setting. When curtailing an individual's liberty, the court must not only consider the fit between means and ends, but also how compelling the government's objective is and the liberty interests that are sacrificed in furthering that objective. ${ }^{158}$

The government's stated objective, as gleaned from its legislative findings, is to aid people who would be "capable of living in the community with the help of family, friends, and mental health professionals, but who, without routine care and treatment, may relapse and become violent or suicidal, or require hospitalization."159 This is a parenspatriae-based, paternalistic goal of treating people for their own good. Implicit in this objective is also a police-power-based goal of protecting society from the violent acts sometimes committed by the mentally ill against innocent bystanders, such as Kendra Webdale. ${ }^{1}$

Despite the compelling nature of these objectives, substantive due process requires that they be balanced against the liberty interests of the mentally ill that are sacrificed when being forced to comply with a court order for AOT. ${ }^{161}$ Kendra's Law requires the patient to accept the treatment but does not allow for medication to be administered

${ }^{157}$ New York State claims that the 2001-2002 Executive Budget "fully funds Kendra's Law programs." 2001-02 Executive Budget Overview, at http://www.ny.us/dob/ pubs/executive/0102littlebook/mh.htm (last visited Feb. 12, 2001). Approved funding includes $\$ 32$ million in General Fund support for AOT and the Medication Grant Program. Id. Additionally, the Budget provides $\$ 125$ million in funding for the Enhanced Community Services program, which "provide[s] case managers for nearly 12,600 additional children and adults ...; 2,000 new supported apartments; and added services for children with serious emotional disturbances." Id. Furthermore, the Budget provides a \$5.2-million increase in funds for the State's supported housing program. Id. Stipends provided by OMH will allow New York City to spend as much as $\$ 10,912$ per bed. $I d$. By the end of the fiscal year, an additional 2700 community beds will be available to New Yorkers with mental illnesses, bringing the total of such beds to 26,400 and representing an increase of almost $40 \%$ since 1995 . Id.

${ }^{158}$ See supra note 139 and accompanying text (outlining the three-pronged substantive due process analysis).

1591999 N.Y. Laws $408, \S 2$.

${ }^{160}$ See Spitzer, supra note 4 ("Kendra's Law is intelligent public policy that will help protect the public and mentally ill from tragic incidents.").

${ }_{161}$ See, e.g., Lynch v. Baxley, 744 F.2d 1452, 1458 (11th Cir. 1984) ("In order to determine whether a substantive [due process] right ... has been violated, it is necessary to balance the liberty of the individual against the demands of an organized society."). 
over the patient's objection. ${ }^{162}$ In practice, however, the patient may have little choice in deciding whether or not to comply with the treatment plan, as noncompliance is one factor that a physician may consider when determining the need for involuntary inpatient treatment. ${ }^{1 / 3}$ Whether or not the physician actually takes noncompliance into account is irrelevant as long as the patient perceives that noncompliance will lead to hospitalization and therefore feels compelled to comply. The right to reject the treatment may be more of an empty right than an actual one.

The patient's liberty is not only restricted by the treatment plan itself, but also by the preliminary procedures. These procedures provide for a court-ordered physical examination during the hearing if the patient had formerly refused to submit to one (allowing the patient to be held for up to twenty-four hours) and a physicianrecommended physical examination in cases of noncompliance (allowing the patient to be held for up to seventy-two hours). ${ }^{164}$ In addition, the patient's liberty may be restricted if the treatment plan requires alcohol and substance-abuse testing.

In O'Conner v. Donaldson, the Supreme Court acknowledged that "a State cannot constitutionally confine without more a nondangerous individual who is capable of surviving safely in freedom by himself or with the help of willing and responsible family members or friends." ${ }^{16}$ Chief Justice Burger's concurring opinion implicated the issue of outpatient commitment by suggesting that a state is justified in asserting its parens patriae power to order outpatient commitment of a nondangerous individual only if it first determines that to do so would be in the patient's best interest and that the patient lacks decisionmaking capacity. ${ }^{166}$

Kendra's Law only partially satisfies the Donaldson requirements needed to justify the sacrifice of liberty entailed in AOT. Kendra's Law does require, in its stated criteria, that AOT be in the patient's

${ }^{112}$ See Kendra's Law: The Process, supra note 23, at 7 ("Even when medications are included in the AOT order, they may not be administered over the individual's objection.").

"3.S See id. ("[A]ny refusal of the individual to take prescribed medication ... may" be considered by the physician in reaching a clinical determination regarding involuntary admission.").

Id. Id at 5,7 ,

422 U.S. $563,576(1975)$.

16r. See id. at 583 (Burger, C.J., concurring); supra Parr I.B (explaining the legal foundation of deinstitutionalization in terms of a state's police, or parens patriae, power). 
best interest. ${ }^{167}$ Kendra's Law, however, does not mandate that decisionmaking capacity be impaired before involuntary outpatient treatment is ordered. ${ }^{168}$ Thus, Kendra's Law does not meet Donaldson's substantive due process requirements. Simply adding a clinical determination that the patient lacks decisionmaking capacity to the criteria could cure this. ${ }^{169}$

In balancing the "liberty of the individual" against "the demands of an organized society," the nondangerous character of the individual must also be considered. ${ }^{170}$ As discussed in Part I.B, Kendra's Law follows a "deterioration" standard, which allows for outpatient commitment for passive harms or before the patient becomes dangerous to herself or others. ${ }^{171}$ Prior to Kendra's Law, the law in New York required that an individual pose an imminent danger to herself or others before civil commitment could be ordered, but these standards were believed by many to be too high. ${ }^{172}$ Waiting until a mentally ill individual deteriorates to the point of dangerousness may make treatment more difficult and may come too late to serve the State's dual goals of protecting the individual and society from violent behavior.

By abandoning the dangerousness requirement, Kendra's Law is vulnerable to a due process challenge on the grounds that the statute is overinclusive and reaches people who are not appropriate candidates for AOT. ${ }^{173}$ This was a major criticism of North Carolina's out-

${ }^{167}$ See N.Y. MENTAL HYG. LAW \$ 9.60(c) (7) (McKinney Supp. 2001) ("[I]t is likely that the patient will benefit from assisted outpatient treatment ....").

${ }^{168}$ Id. $\$ 9.60$ (c) (lacking any such criterion).

${ }^{169}$ Adding such a requirement, however, would circumvent the legislative intent of the statute, as it "contemplates [the] treatment of patients ... who have the capacity to make treatment decisions," especially those who are about to be discharged from the hospital. In re Urcuyo, 714 N.Y.S.2d 862, 868 (N.Y. Sup. Ct. 2000).

${ }^{170}$ Lynch v. Baxley, 744 F.2d 1452, 1458 (1 Ith Cir. 1984).

171 See supra note 46 and accompanying text (noting that Kendra's Law provides for outpatient treatment to prevent relapse or deterioration).

${ }^{172}$ See Gary Spencer, 'Kendra's Law' Gets Backing by Both Parties, N.Y. L.J., May 20, 1999, at 1 (noting that Attorney General Eliot Spizer, prior to the passage of Kendra's Law, expressed that "[t]he thresholds that have to be met to satisfy that [law] are too high").

By abandoning the current dangerousness requirement, preventive commitment statutes also eliminate a critical check on the discretion of judges who issue commitment orders. They are left with the inordinately difficult task of predicting future dangerousness.... Such inappropriate use of preventive commitment laws invites constitutional challenges on the grounds that the statute is overinclusive and not rationally related to the state's objectives.

Wisor, supra note 60, at 169 . 
patient commitment statute. ${ }^{174}$ The criteria used in Kendra's Law, however, include safeguards that make it more likely that only the intended population will come within the reach of the statute. ${ }^{175}$ The New York statute is more narrowly tailored than North Carolina's, which requires neither a history of noncompliance with treatment nor episodes or threats of violent behavior towards self or others. ${ }^{176}$

On balance, Kendra's Law is narrowly tailored and rationally related to its goals of caring for the mentally ill and protecting society from violent behavior caused by mentally ill individuals who are not aware of the nature and consequences of their actions. In fact, the statute may be underinclusive in the sense that it is silent on the issue of those who voluntarily seek mental health care, as did Andrew Goldstein, who ironically sought care many times before he ultimately killed Kendra Webdale. ${ }^{177}$ The State's goals are compelling enough to justify restrictions on the individual's liberty, assuming that only the appropriate candidates for AOT come within the reach of the statute.

${ }^{174}$ See supra note 68 and accompanying text (noting the results of outpatient commitment studies in North Carolina).

175 Ser N.Y. MENTAL HYG. LAW \$ 9.60(c) (4) (Mckinney Supp. 2001) (requiring a history of lack of compliance with treatment that has resulted either in hospitalization at least twice within the last three years or in one or more incidents of serious violent behavior or threats of violent behavior towards self or others within the last four years).

${ }^{17 t}$ N.C. GEN. STAT. $\$ 122 \mathrm{C}-263$ (d) (1) (1996). The North Carolina statute's criteria are:

a. The respondent is mentally ill;

b. The respondent is capable of surviving safely in the community with available supervision from family, friends, or others;

c. Based on the respondent's psychiatric history, the respondent is in need of treatment in order to prevent further disability or deterioration that would predictably result in dangerousness ...; and

d. The respondent's current mental status or the nature of the respondent's illness limits or negates the respondent's ability to make an informed decision to seek voluntarily or comply with recommended treatment.

Id.

${ }^{177}$ Critics note the irony is that Andrew Goldstein had voluntarily sought treatment, again and again, before he killed Webdale.... [H] e requested long-term hospitalization in New York more than once, and yet after each hospitalization-there were more than a dozen in two years-he was discharged in a matter of days with almost no follow-up, even though he was known to be violent.

Carol Ann Campbell, Mentally Ill Could Be Forced into Treatment: State Studies Outpatient Idea, STAR-LEDGER (Newark, N.J.), Aug. 15, 1999, at 15, available at 1999 WL 100377526 . 


\section{Procedural Due Process}

Although Kendra's Law provides important procedural safeguards that minimize the erroneous deprivation of liberty, it is procedurally deficient in a number of respects.

The purpose of procedural due process analysis is "to determine whether a state has provided adequate procedures to minimize efficiently the risk of arbitrary or erroneous deprivations of life, liberty, or property." In Matthews $v$. Eldridge, the Supreme Court outlined the factors that must be considered, as required by procedural due process, when a liberty interest is at stake. ${ }^{179}$

First, [the court must consider] the private interest that will be affected by the official action; second, the risk of an erroneous deprivation of such interest through the procedures used[; third, the] value ... of additional or substitute ... safeguards; and finally, the Government's interest, including the ... fiscal and administrative burdens that the additional or substitute procedural [safeguards] would entail. ${ }^{180}$

This balancing test requires that the procedural protections afforded correspond to the level of infringement on liberty that the state action poses. ${ }^{181}$ Consistent with the sliding scale approach of the Matthews balancing test, all states have granted fewer procedural protections to outpatients than to inpatients, due to the lower restriction on liberty involved in outpatient treatment. ${ }^{182}$

Kendra's Law provides important procedural due process protections, which are crucial to lessening the probability of an erroneous deprivation of liberty. Individuals subject to a hearing are entitled to legal representation from MHLS or from a private attorney at all stages of the proceeding. ${ }^{183}$ Critics from the Mental Health Associa-

${ }^{178}$ Thibodeaux v. Bordelon, 740 F.2d 329, 336 (5th Cir. 1984).

179424 U.S. 319, 332 (1976) (noting that procedural due process constrains governmental decisions that deprive people of liberty interests).

${ }^{180}$ Id. at 335.

${ }^{181}$ See Susan Stefan, Preventive Commitment: The Concept and Its Pitfalls, 11 MENTAL \& PHYSICAL DiSABILITY L. REP. 288, 292 (1987) ("The greater the infringement of liberty represented by the state action, the more procedural protections must be afforded to an individual before he may be subjected to the action.").

${ }^{182}$ See id. ("[S] tates vary greatly in the level of procedural protections they grant to a person subject to commitment ...."). Stefan notes that Georgia comes closest to giving equivalent protections, with North Carolina, offering little more than notice and a hearing by a judge, giving the least procedural protections. Id. North Carolina may justify its procedural deficiency by lack of enforcement mechanisms. Id.; see also supra notes 60-66 and accompanying text (discussing North Carolina's lack of coercion in its statutory commitment scheme).

${ }^{183}$ See N.Y. MENTAL HYG. LAw $\$ 9.60$ (g) (McKinney Supp. 2001) ("The subject of 
tion, a statewide advocacy group for the mentally ill, expressed concern that MHLS is underfunded and is often unable to provide attorneys. ${ }^{1 \times 1}$ Assistant Attorney General Brian Stettin, who drafted the law, has stated, however, that hearings would be delayed until an MHLS lawyer is available.

Other due process protections required by Kendra's Law include the requirement that the examining physician testify as to the rationale supporting the need for AOT. ${ }^{186}$ The patient has the right to crossexamine the physician, or any other adverse witnesses, as well as to call her own witnesses and present any other admissible evidence for the court's consideration. ${ }^{187}$ The law also requires that written notice of the hearing be served on the subject of the petition, the subject's nearest known relative, the MHLS, the AOT program coordinator appointed by $\mathrm{OMH}$, any health care agent appointed by the subject in a health care proxy, and the appropriate AOT mental health director. ${ }^{\text {Is }}$ In addition, the law specifies a method of notice-notice must be written and given personally or by mail. ${ }^{189}$

Despite these provisions, Kendra's Law still raises some procedural concerns. First, the law requires that a court hearing must take place within three days of the filing of the petition. ${ }^{190}$ Attorneys from MHLS have expressed concern that this leaves insufficient time for counsel to prepare, or even to become familiar with their client's case histories. ${ }^{191}$

the petition shall have the right to be represented by the mental hygiene legal service, or other counsel at the expense of the subject of the petition, at all stages of a proceeding....").

"St Spencer, supra note 172 ("[P]atients faced with ... possible confinement should have the same right to assigned counsel as defendants in criminal proceedings,"). yer.").

Ste id. ("We're just not going to have a hearing unless the patient has a law-

dr' St' N.Y. MENTAL Hig. LAw \$ 9.60(h)(2) (McKinney Supp. 2001) ("The court shall not order assisted outpatient treatment unless an examining physician, who has personally examined the subject of the petition within the time period commencing ten days before the filing of the petition, testifies in person at the hearing.").

Id. $\$ 9.60(\mathrm{~h})(5)$.

Nos id. $\$ 9.29$ (McKinney 1996) (outlining the notice requirements for involuntary admission); id. $\$ 9.60(\mathrm{f})$ (McKinney Supp. 2001) (same).

Ser id. $\$ 9.60(f)$ ("The petitioner shall cause written notice of the petition to be given to the subject of the petition and a copy thereof shall be given personally or by mail to the persons listed in section 9.29 of this article ....").

${ }^{\prime \prime *}$ "Set id. $\$ 9.60(h)(1)$ ("Upon receipt by the court of the petition submitted ... the court shall fix the date for a hearing at a time not later than three days from the date such petition is received by the court....").

${ }^{[}+1$ Ste Yael Schacher, Courts, Lawyers Are Gearing Up to Handle Kendra's Law Hearings, N.Y. L.J., Sept. 30, 1999, at I (“[T] he speed with which the hearings must take place 
Since the mentally ill affected by the law are not within a hospital setting, they may be harder for MHLS to reach, contributing to the problem of there being "insufficient time for proper advocacy." the treatment plan may be presented at the time of the hearing or even three business days afterwards (if the petitioner is not a mental health or AOT program director). ${ }^{193}$ This does not allow sufficient time for the patient's attorney to rebut the plan. Finally, the patient may be committed for up to twenty-four hours and ordered to undergo a psychiatric evaluation if the patient refused to do so prior to the hearing. ${ }^{194}$ Yet, there is no provision for attorneys' fees or for experts' fees, thus allowing no opportunity to rebut the findings of such an involuntary examination. Although the court is unlikely to find these issues to be so grave as to vitiate the law's constitutionality, some procedural modifications ought to be considered.

Take, for example, the speed with which the hearings must take place. If the attorneys are not given adequate time to prepare a case or if, as is the reality in some instances, they cannot even locate their clients, then the right to a hearing and the right to an attorney is, to that extent, diminished. When the Matthews balancing test is applied under these circumstances, there may be some risk of erroneous deprivation of liberty. The value of additional safeguards, such as the provision of more hearing preparation time, would be beneficial. Furthermore, in considering the government's interests, it should not entail a substantial administrative or financial burden to extend the period between the filing of the petition and the date of the hearing. Thus, this additional safeguard would further insulate Kendra's Law from claims of unconstitutionality under a Matthews analysis.

\section{Equal Protection}

Under a rational basis standard of review, Kendra's Law likely satisfies the Equal Protection Clause. The Equal Protection Clause states that " $[n]$ o State shall ... deny to any person within its jurisdiction the equal protection of the laws." ${ }^{195}$ A rational basis standard of review is used primarily for economic classifications and classifications dealing with general social welfare regulations. A rational basis standard of review attaches a presumption of validity to the reasonableness of the

may present due process concerns ....").

${ }^{192} I d$.

${ }^{193}$ See Kendra's Law: The Process, supra note 23, at 5.

${ }^{194}$ N.Y. MENTAL. HYG. LAW \$ 9.60(h) (3) (McKinney Supp. 2001).

${ }^{195}$ U.S. CONST. amend. XIV, $\$ 1$. 
classification, placing the burden on the party challenging its legitimacy. Under strict scrutiny review, the burdens are reversed and the state must demonstrate that the classification is the least restrictive means of furthering a compelling state interest.

Strict scrutiny review is used only when a classification threatens a fundamental right or disadvantages a "suspect" class. If the least restrictive means are not used and the statute is determined to be overinclusive, then the statute is considered to be motivated by bias and is declared unconstitutional. If the mentally ill were characterized as a suspect class, then the states' commitment schemes would be subject to a more critical review. The states would be compelled to develop and fund community-based alternatives. If the mentally ill are not afforded suspect class protection, however, then the states' commitment schemes would be considered constitutional if there were a mere rational relation between means and ends, and the states would be under no obligation to provide less restrictive alternatives of treatment.

The mentally ill can arguably be characterized as a suspect class in and of themselves or as a class of individuals whose status correlates with poverty. ${ }^{19 i}$ It is unlikely, however, that the Court would regard either the mentally ill or the indigent as suspect classes. The Court refused to give heightened scrutiny to the mentally retarded in City of Cleburne v. Cleburme Living Center, where the issue was whether a city ordinance that required the mentally retarded to obtain special permits for group homes violated equal protection. ${ }^{197}$ Although the Court invalidated the ordinance, it did so under a rational basis level of scrutiny. In addition, the Court refused to apply a strict level of scrutiny to wealth classifications in San Antonio Independent School District $v$. Radriguez, where the issue addressed was disparate school funding in the poorest property districts. ${ }^{198}$

Although there is a strong argument to be made that the mentally ill do meet the criteria of a suspect class and that classifications affect-

I'" See Klapper, supra note 22, at 828 (arguing that “[w] hile mental illness certainly does affect the middle and upper classes, these individuals ... often have the family support and the financial support to make use of private, non-institutionalized alternatives. Those who are committed, as well as candidates for civil commitment, tend to be, however, the poorest of the poor....").

473 U.S. 432,446 (1985) ("[The equal protection standard] ... affords government the latitude necessary both to pursue policies designed to assist the retarded in realizing their full potential, and to freely and efficiently engage in activities that burden the retarded in what is essentially an incidental manner.").

411 U.S. 1, 2 (1973) (holding that "insofar as the financing system disadvantages those who, disregarding their individual income characteristics, reside in comparatively poor school districts, the resulting class cannot be said to be suspect"). 
ing them should be viewed with suspicion, it is improbable that this will be the case under the current Court's regime. ${ }^{199}$ Therefore, Kendra's Law likely does not violate equal protection, as analyzed under a rational relation basis standard of review. The ends and the means used to achieve them are at least rationally related. The classification made under Kendra's Law can be sustained under this minimal standard of review, where the law is given a presumption of validity and the courts defer to the legislature, reluctant to reverse its judgment. Even if there is an imperfect fit and Kendra's Law is overinclusive, as North Carolina's law is, or does not provide the least restrictive alternative, it still will most likely withstand rational basis scrutiny. ${ }^{210}$

\section{B. State Constitutional Analysis}

New York's constitution parallels the U.S. Constitution, providing that " $[\mathrm{n}]$ o person shall be deprived of life, liberty or property without due process of law." ${ }^{201}$ The due process clause has been interpreted at common law as granting "[e]very human being of adult years and sound mind... [the] right to determine what shall be done with his own body." 202

In In re Storar, the patient was a fifty-two-year old, severely mentally retarded man with terminal cancer of the bladder. ${ }^{203}$ The patient's mother, who was also his legal guardian, refused to consent to blood transfusions that would prolong his life because she felt that the transfusions would extend his discomfort and be against his wishes if he were competent. ${ }^{204}$ The Court of Appeals reversed the Appellate Division decision and held that as the subject was incompetent to refuse such treatment, the application by his mother to discontinue treat-

${ }^{199}$ See Klapper, supra note 22 , at $822-26$ (referring to political powerlessness, segregation, discrimination, and the immutability of mental illness as among the obstacles facing the mentally ill that necessitate heightened scrutiny).

${ }^{200}$ See In re Urcuyo, 714 N.Y.S.2d 862 (N.Y. Sup. Ct. 2000) (rejecting the equal protection challenge and finding that disparate treatment of psychiatric outpatients is warranted); see also infra notes 283-87 and accompanying text (discussing the reasoning of the court in In re Urcuyo).

201 N.Y. CONST. art. I, $\$ 6$.

${ }^{202}$ Schloendorff v. Soc'y of N.Y. Hosp., 105 N.E. 92, 93 (N.Y. 1914), overruled on other grounds by Bing v. Thunig, 143 N.E.2d 3 (N.Y. 1957). In this case, the court went so far as to categorize the violation of the patient's rights as trespass. Id.

${ }^{203} 420$ N.E.2d 64 (N.Y. 1981) (noting that the patient had no reasonable chance of recovery).

204 Id. at 66. 
ment should have been denied. ${ }^{205}$ The court, however, held that the law has "consistently support[ed] the right of the competent adult to make his own decision by imposing civil liability on those who perform medical treatment without consent, although the treatment may be beneficial or even necessary to preserve the patient's life., ${ }^{206}$ In other words, the court acknowledged the patient's right to determine his own course of medical treatment. ${ }^{207}$

In light of Storar; the courts have interpreted the due process clause of the state constitution as affording to involuntarily committed mental patients the fundamental right to refuse antipsychotic medication." In Rivers $v$. Katz, involuntarily committed mental patients sought a declaratory judgment concerning their common law and constitutional right to refuse medication. ${ }^{209}$ The court found a qualified fundamental right to reject medical treatment: "the right to reject treatment with antipsychotic medication is not absolute and under certain circumstances may have to yield to compelling State interests."

In only two circumstances did the court find that the State's interests outweighed the patient's right to refuse treatment. First, the State may exercise its police power to administer medication where the patient poses a danger to himself or society. ${ }^{211}$ In the second instance, the State may exercise its parens patriae authority to forcibly administer medication when the patient is incompetent to make a decision concerning treatment. ${ }^{212}$ Kendra's Law does not have a dangerousness requirement ${ }^{213}$ to justify use of the police power, nor does it have a requirement that the patient be incompetent to make decisions regard-

S S $^{\prime \prime}$ id. (noting that the orders of the lower courts were stayed and the treatments continued pending appeals to that court).

${ }^{2 *+1}$ Id. at 71 (emphasis added).

Sirt id. (holding that the "current law identifies the patient's right to determine the course of his own medical treatment as paramount to what might otherwise be the doctor's obligation to provide needed medical care").

Sit $\ell^{\prime}$ Rivers v. Katz, 495 N.E.2d 337 (N.Y. 1986) (addressing whether and under what circumstances the State may forcibly administer such medication).

Ste id. (elaborating on these claims).

"2a" Id. at 343.

in Id

${ }^{2 \pi 2}$ See id. (“. [T] he sine qua non for the state's use ... of mind-affecting drugs is a determination that the individual to whom the drugs are to be administered lacks the capacity to decide for himself whether he should take the drugs." (quoting Rogers v. OLin, 634 F.2d 650, 657 (1st Cir. 1980), overruled on other grounds by Cuesnongle v. Ramos, 835 F.2d 1486 (1st Cir. 1987))).

Sil Sufra notes $45-47,170-71$ and accompanying text (discussing the requirements for outpatient commitment under Kendra's Law). 
ing treatment to justify use of the parens patriae power. ${ }^{214}$ Furthermore, the law specifies that " $[t]$ he determination by a court that a patient is in need of assisted outpatient treatment commitment under this section shall not be construed as or deemed to be a determination that such patient is incapacitated. ${ }^{215}$

On its face, it appears that Kendra's Law permits a constitutional violation in that it has the potential to compel one to take medication. ${ }^{216}$ Kendra's Law, however, does not authorize forced medication as an enforcement mechanism. ${ }^{217}$ Noncompliance with medication is merely one factor considered by a physician in reaching a clinical determination regarding involuntary inpatient admission. ${ }^{218}$ Although it is arguable that a patient may feel compelled to take medication out of fear that noncompliance will lead to inpatient commitment, the law technically does not authorize forced medication. ${ }^{219}$ In theory, the patient may refuse treatment, but in actuality the patient may feel forced to comply. Still, there is a substantial difference between feeling compelled and actually being compelled, and the law cannot be said to violate the constitution in this respect. ${ }^{220}$

${ }^{214}$ See supra note 40 and accompanying text (noting that impaired decisionmaking is not a prerequisite to administering involuntary outpatient treatment).

${ }^{215}$ N.Y. MENTAL HYG. LAW \$ 9.60(o) (McKinney Supp. 2001).

${ }^{216}$ Opponents argue that Kendra's Law is unconstitutional because it authorizes involuntary medication without requiring a finding of incompetence or an emergency situation. Gutterman, supra note 48 , at 2435 . Kendra's Law, however, does not authorize involuntary medication at all. The patient must accept the treatment. See supra notes 162-63 and accompanying text (adding that in practice, however, the patient may have little choice in deciding whether or not to comply).

${ }^{217}$ A recipient's failure to comply with an order for AOT is not grounds for involuntary civil commitment or contempt of court. Kendra's Law: The Process, supra note 23 , at 7. However, any refusal of the individual to take prescribed medication, or the failure of a test to determine either medication compliance or alcohol or drug use, may be considered by the physician in reaching a clinical determination regarding involuntary admission. $I d$.

${ }^{218} I d$.

219 See supra notes $133-35$ and accompanying text.

${ }^{220}$ The argument can be made that this is a form of soft compulsion, in that the patient may feel forced to comply for fear of the indirect consequences. But this type of compulsion is not all that foreign to the American legal system. For example, although no one is ever "forced" to incriminate themselves in order to exercise their Fifth Amendment rights they still must, in open court, declare that they decline to answer questions that may incriminate them. See U.S. CoNST. amend. V ("No person ... shall be compelled in any criminal case to be a witness against himself ...."). In so doing, the declarants have implicitly incriminated themselves. Even so, being forced to verbally and explicitly "take the Fifth" is not considered self-incrimination through state compulsion, regardless of what the judge and jury are likely to do in response to this kind of constitutional exercise. Indirect penalties for failure to self- 
It is also arguable that Kendra's Law violates the right to determine one's own course of treatment that was recognized in Storar. ${ }^{221}$ However, the patient or the patient's relative, close friend, or other concerned individual is invited to participate in the development of the treatment plan. ${ }^{222}$ Furthermore, as in the case of prescribed medication, the patient is not compelled to comply with treatment, but the individual must at least accept the ordered treatment plan. ${ }^{223}$ Again, noncompliance with the treatment plan may be considered as a factor in making a clinical determination about the need for inpatient treatment, but the individual is not technically forced to comply. ${ }^{224}$ Therefore, the fine line between constitutional and unconstitutional has not been crossed.

\section{POLICY Rationale}

\section{A. Justifications for Kendra's Law}

As discussed throughout this Comment, the two main justifications for AOT lie in the State's police power and the parens patriae power. The police power justifies AOT to protect society from violent acts that mentally ill individuals, such as Andrew Goldstein, sometimes commit after failing to take much-needed medication. The parens patriae power, an essentially paternalistic justification, is based on the rationale that the State may care for those who are unable to care for themselves. Both justifications rest on the fact that many mentally ill patients lack insight into their disease and refuse to take their medication because they deny their sickness. ${ }^{225}$ It is this denial of mental illness that makes compliance unlikely when treatment is voluntary. Kendra's Law attempts to compel compliance with treat-

medicate cannot be considered any worse.

See In re Storar, 420 N.E.2d 64, 71 (N.Y. 1981) (noting that one's right to determine one's medical treatment is paramount to a doctor's obligation to provide necessary care).

${ }^{222}$ Sec Office of Counsel for the New York State Office of Mental Health, supra note 117 (providing an overview of AOT provisions).

Kindra's Law: The Process, supra note 23, at 6.

Id. at 7 .

Sex E. Fuller Torrey \& Mary Zdanowicz, A Right to Mental Ilness?, N.Y. PosT, May 28,1999 , at 35 ("They refuse [to take their medication] because their illness impairs their thinking and they do not think they are sick. They have impaired awareness of their illness."); see also supra note 9 (explaining that such a lack of insight "usually manifests itself as belligerency" towards treatment).

"2: A court which does not issue an order that a mentally ill person is to obtain some type of treatment will have to concern itself with whether the person will 
ment regimens using the force of law (although, as discussed above, the statute does not authorize forced medication). ${ }^{227}$

Despite its lack of dangerousness and impaired decisionmaking requirements, the statute is also narrowly tailored to reach appropriate candidates for AOT. ${ }^{228}$ Omission of these requirements lowers the standard one must attain to be eligible for AOT. This was a legislative choice made to bring more individuals within the scope of the law. ${ }^{229}$ Yet, other criteria reduce the possibility that the statute will be overinclusive and affect individuals who are not appropriate candidates for AOT. ${ }^{230}$ In addition, procedural safeguards are built into the law that lower the risk of an erroneous deprivation of liberty. ${ }^{231}$ However, increasing the length of time between the filing of the petition and the date of the hearing would be helpful to lower this risk even further, and Kendra's Law should be amended to implement this suggestion. ${ }^{292}$

Critics of Kendra's Law argue that the statute has the potential to criminalize patients and to infringe impermissibly on their liberty. ${ }^{2 * 3}$ This argument reflects the "ongoing clash between medical paternalism and individual autonomy." ${ }^{234}$ From another perspective, however, liberty can actually be increased by outpatient commitment for a certain class of individuals who cannot function effectively in the community without such treatment:

To define liberty for such individuals as the "right to be free from inter-

voluntarily come to a clinic or mental health center for the medication prescribed for him and whether the patient's family, "though nodding repeatedly that they want 'whatever is best,' will unconsciously undercut the patient's attempts at community survival."

Wilkinson, supra note 19, at 1341 (quoting David L. Chambers, Alternatives to Cizil Commitment of the Mentally Ill: Practical Guides and Constitutional Imperatives, $70 \mathrm{MrCH}$. L. REV. 1107, 1137 (1972)).

${ }^{227}$ See supra notes 219-24 and accompanying text (discussing the right to refuse treatment).

${ }^{228}$ See supra notes 46,171 and accompanying text (recognizing that the law reaches those who face the risk of deterioration); supra note 40 and accompanying text (recognizing that the law does not require patients to have impaired decisionmaking ability).

${ }^{229}$ See supra notes 168-73 and accompanying text (discussing the balance sought between respecting the individual's liberty and honoring the demands of society).

${ }^{230}$ See supra note 175.

${ }^{231}$ See supra Part II.A.2 (describing the various procedural safeguards under Kendra's Law).

${ }^{232}$ See supra notes 190-94 and accompanying text (discussing the procedural deficiencies of Kendra's Law).

${ }^{233}$ Lara Jakes, Family Applauds Signing of 'Kendra's Law', TIMES UNION (Albany, N.Y.), Aug. 28, 1999, at Al.

${ }^{234}$ Wisor, supra note 60 , at 168. 
ference" is to guarantee that they will continue without the treatment needed to make them truly integrated members of the community. Thus, preventive commitment places its faith in the ability of medical professionals to break the revolving door cycle through treatment of those who, to their detriment, have consistently refused to accept it. This is classic paternalism-restrictions on liberty are justified on the grounds that they are in the patients' best interests and will, in the end, further their ultimate freedom.

Thus, outpatient commitment can ultimately free patients by liberating them from their illnesses.

Liberty is also enhanced by outpatient commitment in the sense that it prevents unnecessary inpatient commitments. Mental health professionals often prescribe treatment based on what is available, rather than on what is appropriate. ${ }^{236}$ In addition, "legal and medical liability have encouraged mental health professionals to err on the side of overcommitment." ${ }^{237}$ Finally, judges may feel uncomfortable releasing mentally ill individuals into the community for fear of the harm that those individuals may later cause. ${ }^{238}$ Prior to the passage of Kendra's Law, not only did New York lack any statute providing for outpatient commitment, but it was also the only state that had a statute specifically prohibiting it. ${ }^{239}$ With the signing of Kendra's Law, New York is now able to offer an alternative treatment that is less restrictive than inpatient commitment. Judges who previously would have ordered inpatient treatment and clinicians who would have recommended it now have another option that is much less restrictive.

\section{B. Potential Barriers}

Critics of outpatient commitment argue that reclassifying the mentally ill as outpatients will not break the cycle of the "revolving door" unless programs are actually implemented that adhere to the State's provisions to create outpatient facilities and services. ${ }^{240}$ Funding has always been a key problem in community mental health care. ${ }^{241}$ If adequate programs and services are not provided, then the reality of outpatient commitment bears no relation to the stated goals

\footnotetext{
245

236. Klapper, supra note 22, at 761.

2.47 Id. at 765 .

2.3\% Id. at 765 n.101.

23upra text accompanying note 49.

2*" Stefan, supra note 181, at 296.

2ni Id.
} 
of outpatient commitment. ${ }^{242}$ With the passage of Kendra's Law, the State's mental health system is taking on an added financial burden as the statute broadens the universe of people subject to commitment. The system must be capable of absorbing the additional committees, which necessitates more funding for extra lawyers, mental health professionals, expert witnesses, and treatment programs. Kendra's Law stipulates that the $\mathrm{OMH}$ provide grants to counties to enable them to assist mentally ill people in receiving medication as they transition from hospitals or correctional facilities to the community while they are applying for Medicaid. ${ }^{243}$ A $\$ 32$-million spending program known as the Medication Grant Program has been approved to implement this stipulation. ${ }^{244}$ Additionally, a $\$ 125$-million spending plan that includes provisions for more case managers and clinicians, as well as provisions for supervised housing units offering mental health services, has been passed. ${ }^{245}$ It remains to be seen whether these budgetary provisions will prove sufficient to implement Kendra's Law.

An additional barrier exists if there are no provisions made to ease the increased burden on the legal system that will result from the need for more lawyers and expert witnesses, as required by the law. For the 2000-2001 fiscal year judiciary budget, only $\$ 500,000$ was allocated towards the implementation of Kendra's Law. ${ }^{246}$ As Kendra's Law guarantees free legal representation from MHLS at all stages of the commitment hearing, the system could easily become overburdened as the demand for lawyers increases. ${ }^{247}$

The burden on the legal system could also appear if renewal petitions flood the courts. Court orders for AOT only last for six months

${ }^{242} I d$.

${ }^{243}$ Kendra's Law: New York's Assisted Outpatient Treatment Law, supra note 156, at 3. The Medication Grant Program, established by Kendra's Law, provides grants for the cost of medications and other services for individuals with mental illnesses moving to the community from local jails, state prisons, or hospitals. Eligibility is limited to individuals with pending Medicaid applications, if they apply within seven days of release or discharge. N.Y. State Office of Mental Health, Kendra's Law: A Look at AOT's First Year, at http://www.omh.state.ny.us/omhweb/omhq/q1200/kendra.htm (last visited Dec. 21, 2000).

${ }^{244}$ See supra note 156 and accompanying text for a discussion of the Medication Grant Program.

${ }^{245}$ See supra note 157 and accompanying text for a discussion of the provisions made for Kendra's Law in the 2001-2002 New York State Executive Budget.

${ }^{246}$ John Caher, Judiciary Gets Boost in Budget of 6 Percent; Lawmakers Even Added to the Court's Proposal N.Y. L.J., May 9, 2000, at 1.

${ }^{247}$ Kendra's Law: The Process, supra note 23 , at 5. 
and may be renewed in one year increments. ${ }^{248}$ Critics also note that this bureaucratic process could potentially divert funds and attention away from treatment programs. ${ }^{29}$ Yet, others disagree and note that outpatient hearings are less expensive and less adversarial than civil commitment trials, which will allow for more compromise, negotiation, and opportunity to customize treatment plans. ${ }^{250}$

One final barrier to the success of Kendra's Law involves potential practical problems. For example, North Carolina's experience indicated that issues, such as lack of transportation to the mental health center or lack of reminders about appointments, reduced compliance with outpatient treatment. ${ }^{251}$ The success of outpatient treatment in North Carolina depended on the commitment and the attitudes of the mental health staff. ${ }^{252}$ North Carolina dedicated $\$ 2200$ to $\$ 2300$ each year per outpatient, which permitted case managers to "bring treatment to the client rather than requiring the client to come to a mental health center to be treated." ${ }^{253}$ If New York wants to be as successful as North Carolina, the legislature must be ready to make a financial commitment and the staffs at the mental health centers must be fully dedicated.

\section{RECENT DEVELOPMENTS AND CASE LAW}

Few decisions have been reported since the enactment of Kendra's Law. The few cases reported under the statute involve statutory interpretation and challenges to constitutionality. The first reported Kendra's Law decision, In re Arden Hill Hospital, involved the costs of implementing a treatment plan. ${ }^{254}$ The court held that costs not covered by insurance, Medicaid, or otherwise "are to be borne by the local government through the duties imposed by this law on the director of community services. ${ }^{255}$

${ }^{24 \times}$ Id. at 7.

23:" Schacher, supra note 191.

IJ" Id.

Wilkinson, supra note 19, at 1344.

$2:$ See id. (noting that mental health centers in North Carolina were willing and able to provide treatment to outpatient-committed clients).

Id.

703 N.Y.S.2d 902 (N.Y. Sup. Ct. 2000).

Id. at 907 . The court also stated, however, that under certain circumstances the respondent or petitioner should be responsible for the costs: "Certainly if the respondent has financial resources, whether it be through employment or funds established by trust or the proceeds of a lawsuit, it would appear that the respondent should be responsible for the costs of his or her own treatment and for the costs of obtaining that 
The second case to arise under Kendra's Law, In re Sullivan, demonstrates that the specificity in pleading required under Kendra's Law is "not to be taken lightly" and that the specificity requirements will not be viewed "as simply technical pleading requirements." court dismissed a petition filed pursuant to Kendra's Law because the physician's supporting affidavit failed to plead sufficient facts to demonstrate that the respondent met the criteria for AOT. ${ }^{257}$ Instead, the physician's affidavit made conclusory statements without any supporting documentation. A supplemental affirmation was submitted, which, although it contained specific facts that demonstrated the respondent's violent propensity, was also found insufficient, because it was neither based upon the physician's personal knowledge nor was the source of the information identified. ${ }^{258}$ Under Kendra's Law, the court noted that the pleading sufficiency requirements not only protect due process rights, but also allow the respondent to adequately prepare a defense. ${ }^{259}$ Furthermore, the court pronounced that the constitutional safeguards attach to the petition itself, and not just to the hearing, in order to permit the court to make an informed decision. ${ }^{260}$

In a similar case involving the same physician, In re Sullivan, the court denied the patient's motion to dismiss a physician's petition filed pursuant to Kendra's Law, holding that the physician-patient evidentiary privilege did not prevent a treating physician from submitting testimony or an affidavit in support of a petition. ${ }^{261}$ In this case,

treatment." $I d$. at 906 . Yet, this responsibility arises not only by virtue of being the petitioner, but by law independent of the statute that imposes a legal responsibility on the person for the respondent, such as where the petitioner is the spouse or parent of the respondent. Id. at 907 .

${ }^{256} 710$ N.Y.S.2d 853, 856 (N.Y. Sup. Ct. 2000).

${ }^{257}$ Id. at 857 ("Clearly, these allegations, which are nothing more than conclusions, not facts, are insufficient."). But see In re Sarkis (Robinson), N.Y. L.J., Aug. 18, 2000, at 29 (N.Y. Sup. Ct. Aug. 17, 2000) (denying a patient's motion to dismiss for alleged lack of specificity, stating that "Dr. Theventhiran's affirmation, predicated on an inartfullypleaded combination of personal knowledge (e.g., 'clinical observations') and information and belief (e.g., respondent's medical 'records'), may be deemed legally sufficient to cure any perceived defects in the underlying petition").

${ }^{258}$ In re Sullivan, 710 N.Y.S.2d at 857.

${ }^{259}$ Id. at 856 .

${ }^{260} I d$.

${ }^{261} 710$ N.Y.S.2d 804 (N.Y. Sup. Ct. 2000) (holding that the physician-patient evidentiary privilege only protects confidential communications, but does not protect facts); see also Amin v. Rose F., N.Y. L.J., Dec. 7, 2000, at 25 (N.Y. Sup. Ct. Dec. 6, 2000) (" $[\mathrm{I}] \mathrm{t}$ is clear that the Legislature intended and desired for the subject's treating psychiatrist to be intimately involved with the various aspects of assisted outpatient treatment, and thereby implicitly waived the physician-patient privilege for the purposes of 
the testifying physician was also the respondent's treating psychiatrist, prompting the respondent to claim the physician-patient privilege to prevent the physician from submitting testimony in support of the petition. ${ }^{2 i 2}$ The court held, however, that the privilege is not absoluteit only protects confidential communications, with the burden of proof lying with the party claiming the privilege. ${ }^{263}$ Additionally, the court stated that nothing in Kendra's Law prevents a treating physician from being the examining physician, as long as she is not the petitioner. ${ }^{204}$

In re Dailey was a case of statutory interpretation challenging the meaning of the provision of the statute that requires at least two hospitalizations within the preceding thirty-six month period. ${ }^{265}$ The two issues presented were: (1) whether the period of hospitalization immediately prior to the proceeding was to be counted towards the statutory requirement of at least two hospitalizations, and (2) whether that period of hospitalization was to be added to the required thirtysix months. ${ }^{26}$ The court concluded, after a reading of the legislative history coupled with this section of the statute, that "the section seeks only to expand the number of months which a petitioner can look back to thirty-six months prior to the current hospitalization and does not exclude the acts of non-compliance with treatment and the current hospitalization itself from consideration for an AOT order." ${ }^{267}$

Finally, the most recent court decisions to arise under Kendra's Law have addressed the constitutional challenges to the law. ${ }^{268}$ The In re Urcuyo court rejected the patients' claim that, absent a requirement that a court find by "clear and convincing" evidence that a patient lacks the capacity to make a reasoned treatment decision, Kendra's Law violates the due process clause of the New York State Constitu-

assisted outpatient treatment.").

intil In re Sullivan, 710 N.Y.S.2d at 805.

2 Id. $I$.

Id. at 806 .

713 N.Y.S.2d 660 (N.Y. Sup. Ct. 2000).

Id. at $662-63$.

${ }^{257}$ Id. at 663; see also In re Sarkis (Robinson), N.Y. L.J., Aug. 18, 2000, at 25 (N.Y. Sup. Ct. Aug. 17, 2000) (holding that the patient's current hospitalization may be included as among the two hospitalizations required within the preceding thirty-six month period). The In re Dailey court also notes a recent proposal in the New York State Senate, S. 7814, 223d Ann. Legis. Sess. (N.Y. 1999), which, in part, seeks to clarify N.Y. MENTAL HYG. LAW $\$ 9.60$ (c) (4) (1) (McKinney Supp. 2001). 713 N.Y.S.2d at 663 n.3.

See In re Martin, N.Y. L.J., Jan. 9, 2001, at 31 (N.Y. Sup. Ct. Jan. 8, 2001) (stating the respondent's challenge to Kendra's Law as a violation of constitutional due process protections); In re Urcuyo, 714 N.Y.S.2d 862 (N.Y. Sup. Ct. 2000) (same). 
tion, the common law of New York State, and the equal protection clauses of the New York State and U.S. Constitutions. ${ }^{269}$

Respondents relied on Rivers $v$. Katz ${ }^{270}$ in support of their contention that the due process clause of the New York State Constitution "require[s] a finding of incapacity before the court can order a course of medical treatment." 271 The court in Rivers held that an involuntarily committed psychiatric patient could not be forcibly medicated against her will absent a judicial determination that she lacked the mental capacity to make treatment decisions. ${ }^{272}$ As the In re Urcuyo court explained, however, unlike patients in Rivers hearings, "Kendra's Law contemplates treatment of patients who .... do not require the forcible administration of medication" and who have the capacity to make treatment decisions, especially those patients who are in the hospital facing imminent discharge. ${ }^{273}$ It is clear that this was the legislative intent, as the statute provides for the active participation of the patient in the development of the treatment plan. ${ }^{274}$ Thus, "[t]he practical result of requiring a lack of capacity component to be added to the statutory scheme would be to eliminate the option of an Assisted Outpatient Treatment order for many patients. ${ }^{275}$

Respondents further argued that even though the statute does not provide for the forcible administration of medication, a patient's right to refuse medication is violated by the threat of "arrest upon noncompliance with the plan." ${ }^{276}$ As the court explained, however, “failure to comply with an [AOT] order shall not be grounds for involuntary civil commitment or a finding of contempt of court." ${ }^{277}$ Instead, failure to comply with the treatment plan only "leads to the heightened scrutiny of physicians for a seventy-two hour evaluation period, but only after a physician has determined that the patient may be in

\footnotetext{
${ }^{269}$ In re Urcuyo, 714 N.Y.S.2d at 873.

270495 N.E.2d 337 (N.Y. 1986).

${ }^{271}$ In re Urcuyo, 714 N.Y.S.2d at 867 . For a discussion of Rivers, see also supra notes 208-12 and accompanying text.

${ }^{272}$ Rivers, 495 N.E.2d at $343-44$.

${ }^{273}$ In re Urcuy'o, 714 N.Y.S.2d at 868 . "In this court's experience presiding over hearings pursuant to MHL 9.60 it has become clear that many of the subject-patients, especially those that are still in the hospital and are to be imminently discharged, have the capacity to make treatment decisions." Id. at 868 n.2.

${ }^{274}$ See id. at 868 ("Kendra's Law envisions a process where a patient with capacity actively participates in the planning of his or her own treatment plan.").

275 . at $868 \mathrm{n} .2$.

${ }^{276} I d$. at 869.

${ }^{277}$ Id. (quoting N.Y. MENTAL HYG. LAW \$ 9.60(n) (McKinney Supp. 2001)).
} 
need of involuntary admission to a hospital."278 Furthermore, this seventy-two hour detention period was deemed to be a "reasonable response to a patient's failure to comply with treatment when it is balanced against the compelling state interests that are involved." ${ }^{279}$ The State has a legitimate interest because once a court makes an AOT order based on clear and convincing evidence, it has then been adjudicated that failure to comply with the treatment plan is likely to make the patient dangerous to herself or others. ${ }^{280}$ Under the State's parens patriae and police powers, the State has a legitimate interest in protecting the patient herself, as well as society, from the patient's dangerous tendencies. ${ }^{281}$ The court further explained that the response is reasonable because of precedents in case law and in the Mental Hygiene Law that have "allowed physicians to consider a patient's conduct in the community, including a history of relapses or deterioration, in deciding dangerousness. ${ }^{282}$

The court in In re Urcuyo also rejected the patients' equal protection challenge. The patients argued that the state legislature had created three classes of individuals who potentially may be deprived of their fundamental right to control their treatment: alleged incapacitated persons, who are "individuals subject to guardianship proceedings pursuant to MHL article $81 \ldots$, involuntary psychiatric inpatients and psychiatric outpatients. ${ }^{283}$ These three classes, the patients argued, were subject to disparate treatment not supported by any compelling state interest. Specifically, the patients claimed that for

Id. at 870 .

$2 \pi 4$ Id.

Id.

Id $x$.

: ${ }^{\prime 2}$ Id. at 871 . The cases the court cites for this proposition are Seltzer $v$. Hogue, 594 N.Y.S.2d 781 (N.Y. App. Div. 1993) (holding that physicians could consider a patient's behavior in the community after discharge in making a determination of dangerousness), and In re Francis, 618 N.Y.S.2d 660 (N.Y. App. Div. 1995) (same), affd 663 N.E.2d 881 (N.Y. 1995). The court cites N.Y. MENTAL HYG. LAW § 9.13(b) (McKinney 1996) as precedent for the proposition that the seventy-two-hour detention period is a reasonable response. See Project Release v. Prevost, 722 F.2d 960, 966 (2d Cir. 1983) (holding constitutional N.Y. MENTAL HYG. LAW \$9.13(b)). Section 9.13(b) provides that a voluntarily committed patient who gives written notice to the hospital director of his desire to leave must be promptly released from the hospital, unless the director reasonably believes the patient needs involuntary treatment. N.Y. MENTAL HYG. LAW $\$ 9.13(\mathrm{~b})$. In that instance, the patient may be detained for up to seventytwo hours from the patient's written notice. During the seventy-two-hour period, the director must have two physicians examine the patient and report their conclusions to the director, who must then either release the patient or seek a court order authorizing involuntary retention. Id.

In re Urcuyo, 714 N.Y.S.2d at 872. 
the first two classes of individuals, "there must be a finding by clear and convincing evidence [of incapacity] to mak [e] ... treatment decisions," while for the third class (those targeted by Kendra's Law), "no such finding is required by the statute."284 Rejecting the argument, the court found that there is no equal protection violation, first, because individuals subject to AOT orders are not deprived of their fundamental right to refuse medical treatment and are only subject to a "constitutionally acceptable procedure to ensure that the patient is evaluated by a physician." abridgement of the patients [sic] fundamental right to refuse medical treatment was involved," disparate treatment is warranted because, unlike the other two categories of individuals, subjects of AOT are "likely to decompensate and become dangerous again if they fail to follow their treatment plans. Clearly, the state has a compelling interest in taking measures to prevent these patients who pose such a high risk from becoming a danger to the community and themselves."28i Kendra's Law, the court continued, is "narrowly tailored to achieve these goals within the framework of the involuntary and emergency commitment procedures of the Mental Hygiene Law."

In In re Martin, the court also rejected the patient's challenge that Kendra's Law violates due process and equal protection, absent a finding of incapacity to make reasoned treatment decisions, and the contention that a patient subject to an outpatient treatment order who fails to comply with the treatment plan "be afforded notice and an opportunity to be heard prior to being arrested and detained for a 72 hour observation period." 288

As in In re Urcuyo, the respondent in In re Martin relied on Rivers $v$. $\mathrm{Katz}^{289}$ in support of the claim that the due process clauses of the New York State and U.S. Constitutions require a specific finding that the patient lacks capacity to make reasoned decisions about treatment. ${ }^{2 \times 4}$ The court disposed of this argument in the same manner it did in In re Urcuyo, but added an additional element. ${ }^{291}$ The court stated that re-

284 Id.

285 Id. at 873.

$2867 d$.

287 Id.

${ }^{288}$ N.Y. L.J., Jan. 9, 2001, at 31 (N.Y. Sup. Ct. Jan. 8, 2001).

289495 N.E.2d 337 (N.Y. 1986).

290 In re Martin, supra note 288.

291 See supra notes 270-82 and accompanying text (explaining that such an argument makes AOT impractical and that the short-term detention permitted was reasonable). 
quiring a finding that the patient is unlikely to participate voluntarily in treatment in the context of $\mathrm{AOT}$ is analogous to requiring a finding of lack of capacity in the context of the forcible administration of medication because "the finding is sufficient to justify the less onerous restrictions on the patient's freedom." ${ }^{292}$

The court also rejected the patient's claim that the patient must be afforded notice and opportunity to be heard prior to arrest and seventy-two-hour detainment for failing to comply with a treatment plan or, in other words, that "only a court may order such confinement or detention, rather than a physician, as set forth in the statute." The court rejected this claim based on the fact that the statute requires a judicial finding, by clear and convincing evidence, that the patient will pose a danger to himself or others if he fails to comply with treatment, and that the statute does not provide for "automatic" confinement upon failure to comply with the treatment plan. ${ }^{294}$ The patient also "contend[ed] that the Fourth Amendment to the United States Constitution and its New York State constitutional counterpart authorize the seizure and detention of an individual only where there are reasonable grounds to believe that the person seized is dangerous." The court stated that it believed that a physician's clinical judgment as set forth in the statute meets this "probable cause" standard, especially in light of the fact that it is well established in the law that this standard is satisfied by a police officer's reasonable belief that a psychiatric examination is necessary. ${ }^{246}$ The court also went on to say that due process does not require an additional hearing prior to confinement where "the existence of a potential emergency makes such a prior hearing impracticable" and that a "post-deprivation' remedy provides adequate due process in such instances." ${ }^{297}$

Respondent's equal protection claim was also rejected by the In re Martin court. The patient alleged that a comparable statute, Criminal Procedure Law section 330.20, provides for notice and opportunity to be heard prior to reconfinement in the case of criminal defendants who have been acquitted on the grounds of insanity. ${ }^{298}$ The crucial

In re Martin, supra note 288.

W*3. Id.

$2: 4$ Id.

Id. (internal quotation omitted).

z':" See id. ("Surely, if Fourth Amendment standards are satisfied by the reasonable belief of a police officer, the clinical judgment of a physician similarly satisfies those standards.").

${ }^{2 ! 7}$ Id.

Id. 
difference is that under that law, the criminal defendant would have been originally released only upon a determination that the defendant "no longer has a dangerous mental disorder and is no longer mentally ill," in contrast to the situation of a patient under Kendra's Law, who has been determined, based on clear and convincing evidence, to be mentally ill. ${ }^{299}$ The court found this to be a rational basis for the distinctive treatment and found no equal protection violation. ${ }^{300}$ The court went on to praise the law as a solution to the "serious void in New York's system of caring for the mentally ill" and further stated that

Kendra's Law is a carefully crafted, well drawn and narrowly tailored enactment specifically directed toward the solution of serious problems faced by society and by mentally ill persons. The statute is mindful ofindeed solicitous toward-the civil liberties of the patients, while protecting the vital interest of society in the safety of its citizens.

Despite these positive judicial statements, it is too soon to tell whether Kendra's Law, as applied, will be regarded as a success or failure. As of yet, it is "neither a boon nor a bust." applied its provisions seriously, with conscious awareness of the incorporated due process protections. ${ }^{303}$ In a recent open forum at the Association of the Bar of the City of New York, the general consensus was that Kendra's Law "has been a boon to those who need treatment." ${ }^{304}$ The panel of experts strongly disagreed, however, about the legality of the increasing number of court orders for AOT, especially in New York City. ${ }^{305}$ The two major concerns emerging from the panel discussion were: (1) that "court orders could be used to ration care in New York City, which has a much higher ratio of court orders to vol-

${ }^{299}$ Id. (internal quotation omitted).

${ }^{300} \mathrm{Id}$.

${ }^{301}$ Id.

${ }^{302}$ Susan L. Pollet, Has Kendra's Law Been a Boon or a Bust?, N.Y. L.J., Oct. 23, 2000, at 1 .

${ }^{303}$ Thus far, the courts have not abused their authority to order AOT. During the law's first 14 months, only 512 AOT orders were given, out of 3169 individuals evaluated. Laura Parker, N.Y. Law Breaks Grounds in Court-Ordered Care, USA TODAY, Feb. 12, 2001 , at $7 \mathrm{~A}$. Of the individuals evaluated, 837 were provided with enhanced services, but not court-ordered treatment, and 1308 were determined not to be in need of services or treatment. Id.

${ }^{304}$ Yael Schacher, Experts Disagree over the Success of Kendra's Law, N.Y. L.J., June 30, 2000 , at 1 .

${ }^{305}$ See id. (stating that as of June 14, 2000, New York City accounted for 131 granted petitions out of a total of 163 petitions granted statewide). 
untary treatment agreements than any where else in the state," (2) that "judges-who may be motivated more by protecting the public rather than compelling patients to get needed treatment-may decide to err on the side of caution." ${ }^{\text {307 }}$ Although these are legitimate concerns, the success of Kendra's Law will likely depend more on the level of financial commitment to involuntary outpatient programs and the quality of services provided.

\section{CONCLUSION}

With the passage of Kendra's Law, New York sought to provide a less restrictive alternative for treating the mentally ill. The law demonstrates that the State's police power and parens patriae interests can outweigh the abridgement of a patient's liberty interests. The State has the authority, through the police power, to protect society from danger. The State also has the power, through its parens patriae authority, to care for those who are unable to care for themselves. Kendra's Law has lowered the bar for bringing mentally ill individuals within the mental health care system, but has done so in a manner that selects only appropriate candidates for AOT.

Furthermore, the restriction on liberty that a Kendra's Law outpatient faces must be weighed against that patient's eventual increase in liberty and autonomy. Absent an outpatient alternative, the mentally ill individual either would be free from any interference, but a prisoner of her own illness, or would be subject to inpatient commitment in a system that gravitates to over-commitment when no other alternatives are available. Outpatient commitment under Kendra's Law provides a third option that can free the mentally ill both from their illnesses and from physical confinement.

Kendra's Law is sound under both federal and state constitutions. Substantive due process requires balancing an individual's liberty and autonomy interests against a compelling state interest. The State's objectives, including aiding individuals who need routine care to survive in the community at large, while simultaneously protecting the public from violent acts committed by those people who refuse to take their medication, override the patient's individual liberty interest. Furthermore, procedural safeguards make an unjust deprivation of liberty less likely. Finally, the state constitutional and common law right to

Id. During the law's first 14 months, 415 out of 512 court orders for AOT were in New York City. Parker, supra note 303.

Schacher, supra note 304. 
refuse medication is not violated because Kendra's Law does not strip outpatients of this right.

For Kendra's Law to be implemented successfully, the legislature must commit financially to making it work. Adequate funding is critical to ensure the availability of community treatment programs. A court order for AOT is meaningless unless the resources are available to implement it. It is also crucial that staffs at mental health centers be dedicated to the programs. Only then will the goals of Kendra's Law be realized. 
* $* \quad * \quad * \quad * \quad *$ 


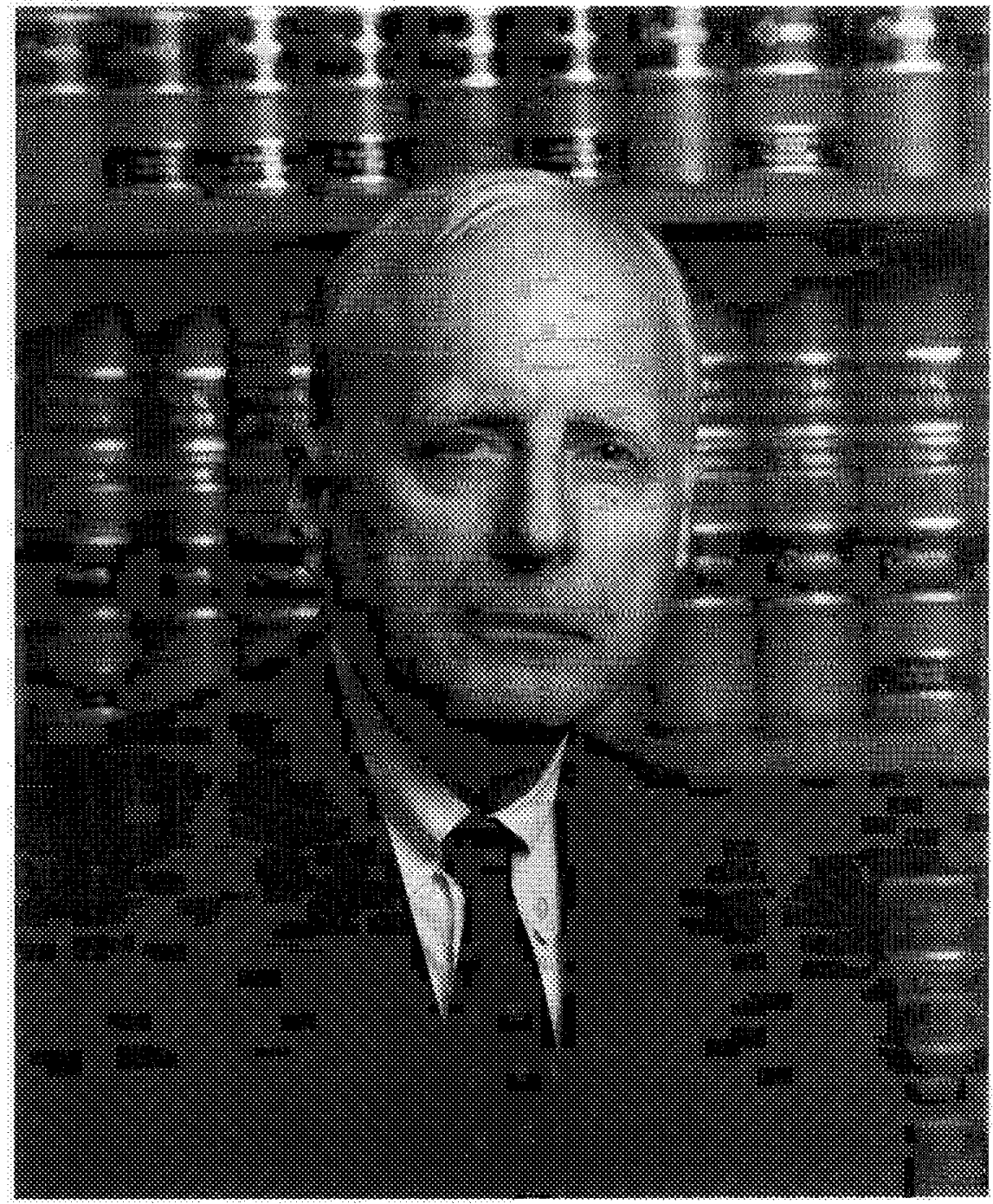

CHIEF JUNGE EDWARD R. BECKEX

Thirty years ago, Chief Judge Edward R. Becker of the United Statses Court of Appeals for the Third Circuit was appointed to the 3. dwal berch. On behalf of his current and former clerks, colswaxus, and students, the Roard of Editors of the Uniwersity of Twosyluania Law Revinu takes great pleasure in publishing this Tribute in recognition of Chief Judge Becker's profound jurisprudence and extrordinary contributions to the administration of justice. 